\title{
A REVIEW ON PULSATING HEAT PIPES: LATEST RESEARCH, APPLICATIONS AND FUTURE SCOPE
}

\author{
Chirag Dave ${ }^{1, \star}$, Prajwal Dandale², Kushagra Shrivastava², Dashrath Dhaygude², Kavi \\ Rahangdale ${ }^{2}$ and Nilesh More ${ }^{2}$
}

\begin{abstract}
Heat pipes have become popular as passive heat dissipation devices for many applications ranging from electronics to heat recovery in recent years. Pulsating Heat Pipe abbreviated as PHP is an exclusive category of a heat pipe which does have wick structure. It transfers heat between its evaporator and condenser sections due to the to and fro movement of working fluid caused due to the continuous change of phase taking place in it. Its operation involves combined hydrodynamic and thermodynamic effects causing the two-phase flow, making it difficult to fully understand it. Nevertheless, the PHPs have drawn the attention of investigators worldwide due to their simplicity in construction and a wide range of applications requiring high heat flux transfer. This review starts with a prologue of the attempts made by various investigators to explain the operation of PHPs through mathematical modeling. Later numerical simulations through Computational Fluid Dynamics of PHP performed by various investigators have been discussed. Review of latest experimental investigations performed on PHPs, is presented concisely in a tabular form. Novel concepts like the application of nanofluids, magnetic field and surfactant, applied for enhancing the performance of the PHPs have been discussed. At the end, applications of PHP and future scope have been discussed.
\end{abstract}

Keywords: Pulsating Heat Pipes, CFD, Thermal Resistance, Fill Ratio.

\section{INTRODUCTION}

Electronic components are undergoing continual miniaturization which has resulted demand for device which could help dissipation of higher heat flux. Heat pipes making use of wick structure have proved to be a blessing for such applications till now. But the presence of wick structure in a general heat pipes limits their further miniaturization, calling for an alternative design without wick structure. A Pulsating Heat Pipe (PHP) also called as Oscillating Heat Pipes (OHP) in some literature, introduced by Akachi could prove to the best substitute to conventional heat pipes for dealing with above problem [1]. Unlike conventional heat pipes, the PHP does not have a wick structure and thus has a high manufacturability, making it as the promising technologies for electronic cooling, heat exchanger, cryogenics, the spacecraft thermal management system, etc [2]. This relatively new technology of heat transfer has the prospective to meet the present as well future requirements of the not only electronics devices but also other applications. PHPs basically comprise of meandering tube. It may be with one or more turns. The tube is first vacuumized and later some suitable working fluid is filled in it. The tubes generally are capillary tubes. PHPs are of mainly two different configurations either Closed loop i.e. CLPHP which is displayed in Figure 1 or Open Loop i.e. OLPHP which is displayed in Figure 2. The OLPHP is also called as Closed End PHP in some literature. CLPHP is the meandering tube, the ends of which are joined to form a continuous loop. OLPHP/CEPHP is the one in which two ends of the tube are not coupled to form a continuous loop instead the ends are sealed.

In general, most of the PHPs comprises of three sections namely evaporator, and condenser sections. PHP without adiabatic have also been investigated. These sections are interconnected by several looping channels. Input heat from any device, is supplied to evaporator section while the heat is dissipated to some thermal reservoir from the condenser section. The adiabatic section which is in between aforementioned sections is optional across which there is no transfer of heat. The operation of PHP is quite complex. When heat enters the PHP at its evaporator section the working fluid in it evaporates. This leads to rise of vapor pressure. This is followed by growth of the bubbles. This causes transport of liquid in direction of the condenser, generally at lower temperature compared to evaporator, due to contact with heat sink. Transfer of heat from the condenser

\footnotetext{
This paper was recommended for publication in revised form by Regional Editor Erman Aslan

${ }^{1}$ Independent Researcher, Pune, Maharashtra, India,

${ }^{2}$ Department of Mechanical Engineering, Sinhgad College of Engineering, Vadagaon (Bk.), Maharashtra, India,

*Email: chirag.scoe@gmail.com

Orcid id: 0000-0002-7457-7852, 0000-0003-0202-5423, 0000-0003-0906-4011, 0000-0002-3402-775X, 0000-0002-9902-9297,

0000-0002-5518-4578

Manuscript Received 13 March 2019, Accepted 18 June2019
} 
section to some heat sink which may be surrounding air or cooling water causes reduction in vapor pressure and causes condensation of the vapor in the bubbles. This formation and collapse of bubbles results to and fro motion of the working fluid within the flow channel, hence the name "Oscillating Heat Pipe". The liquid slugs in the PHP transfers heat in form of sensible heat while vapor plugs transfers heat in form of latent heat.

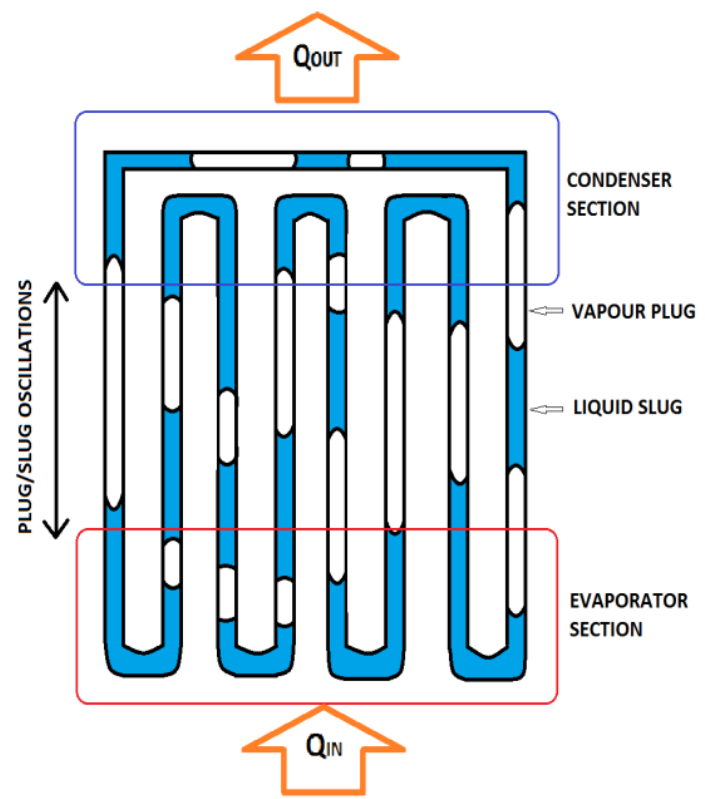

Figure 1. CLPHP schematic

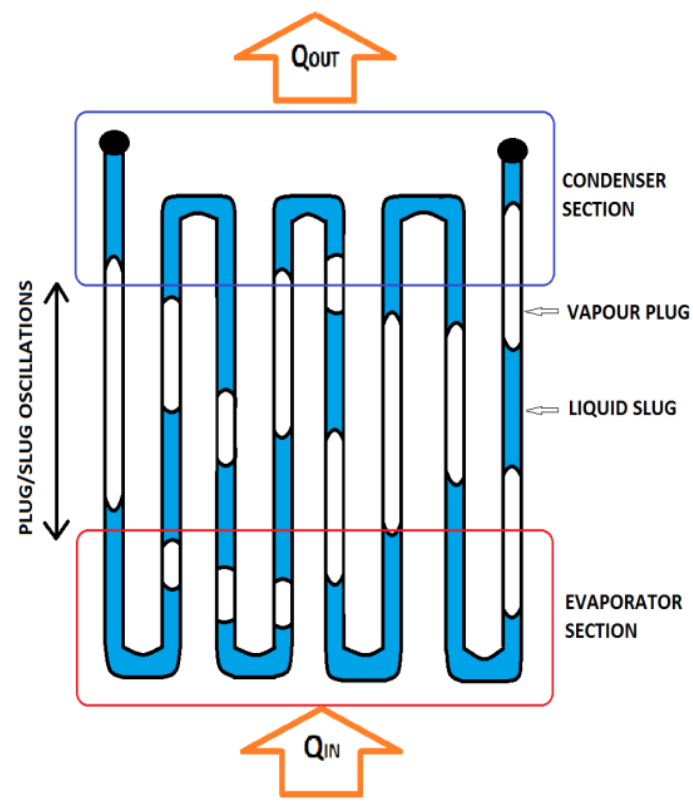

Figure 2. OLPHP schematic

The present work reviews the recent theoretical research and experimental works performed on the PHPs. Although most of the present experimental investigations have mostly focused on the thermal performance of the PHPs, there have been some theoretical investigations attempted to analytically and numerically model the complex fluid dynamics of oscillating flow involving two phases of the working fluid and the resulting transfer of heat. A comprehensive report of theoretical, numerical and experimental investigations has been presented in this review article which includes details of the type of PHP being investigated under various conditions and the conclusions drawn by the investigators. This is followed by discussion of research papers focusing on various applications of PHP proposed by different investigators and the future scope.

\section{MODELING OF PULSATING HEAT PIPES}

Most of the literature on PHP are experimental investigations as its operation involving combined hydrodynamic and thermal effects makes it complex to fully understand and model it. Nonetheless noteworthy mathematical modeling, theoretical analysis or numerical simulations of PHPs have been attempted by various investigators with different approaches as they help disclose performance of any device for various operation conditions at low cost. The subsequent two sections discusses the attempts made by different researchers to present theoretical model of PHP and simulation of same through CFD respectively.

\section{Theoretical Modeling of PHPs}

One of the apparent approaches for theoretical modeling of any thermal system is the application of fundamental conservation equations for a specified control volume. Yuwen Zhang et al. [3] proposed thermal modeling of both CLPHP and OLPHP. Their investigation aimed at analyzing the flow of slugs of liquid and plugs of vapor in a PHP. For finding solution to the three conservation equations, they used explicit finite difference scheme. They established that in case of numerical model gravitational force did not affect the performance of top heat mode OLPHP. The results also showed that exchange of sensible heat was the chief cause for the transfer of heat and both PHPs stopped operating at higher charge ratios. Since modeling of PHP is difficult by traditional analysis, Sameer K. et al. [4] proposed modeling of PHPs using Artificial Neural Network 
(ANN). They made use of multi-layer fully connected feed forward ANN. It was trained and later validated with the help of available experimental test data for a vertical CLPHP for various inputs and fill ratios varying from $0 \%$ to $100 \%$. The working fluid was ethanol for this study. They found that for the filling ratio ranging from $20 \%$ to $80 \%$, the predictions made using ANN were satisfactory. Sameer K. et al. [5] has put forward a promising semi-empirical equation for predicting the behavior of CPHP. They employed non-dimensional numbers and equation proposed by them is given as,

$$
\begin{gathered}
\dot{q}=\left(\frac{Q}{\pi D_{i} \cdot N \cdot 2 L_{e}}\right) \\
=0.54(\exp (\beta))^{0.48} \mathrm{Ka}^{0.47} \operatorname{Pr}_{\text {liq }}^{0.27} \mathrm{Ja}^{1.43} \mathrm{~N}^{-0.27}
\end{gathered}
$$

The correlation is valid for situations where $\mathrm{Bo} \leq \mathrm{Bo}_{\text {crit }}$ (approximately equal to 2 ), above which the device does not function as a PHP. Implementation of Standard least square curve fitting technique along with Gauss elimination method caused an overall drift in predictions within $\pm 30 \%$. Dobson R. T. et al. [6] proposed that the Open Oscillatory Heat Pipe (OOHP) could serve as simple model to study and understand the complex physical behavior PHPs for which a satisfactory theoretical model had yet not been published. They presented the theoretical model taking gravity, surface tension, friction and pressure into consideration. For the same they utilized control volumes of vapor slug, liquid plug and liquid film. An experimental model was built and then tested which validated the theoretical model to noteworthy extent. He also recommended further investigation of water pumping ability of the OOHP which could be exploited for some applications. P. Sakulchangsatjatai et al. [7] presented a model to simulate thermal performance of a OLPHP and a CLPHP. They applied the explicit finite element method. Both the PHPs were considered to be operating at top heat mode. The output predicted by the proposed model matched with the available experimental data. They concluded that increasing the evaporator length resulted decrease in heat flux while increasing the inner diameter resulted increase in heat flux. It was also concluded that PHP with water as the working fluids had maximum $\mathrm{R}_{\text {th }}$ while the one with $\mathrm{R} 123$ has the minimum $\mathrm{R}_{\text {th. }}$.

Attempts have been performed to achieve mathematical model of Pulsating Heat Pipes by comparing the action of its flow pulsations to equivalent spring-mass-damper system. M. A. Hanlon et al. [8] presented a model of a PHP focusing on the driving force which leads to the to and fro motion of the working fluid in it. They considered the difference in temperature between the condenser section and evaporator section to be the required driving force. The equation developed was compared with the governing equation for mechanical vibrations for system with forced damping. From the results the authors suggested that the to and fro motion in a PHP could be controlled by changing the difference in temperature between the evaporating section and condensing section. P. Chareonsawan et al. [9] established a mathematical model of an OLPHP with evaporator at bottom mode. The results attained from it when weighed against with the experimental results showed an error range of $\pm 13 \%$. It was observed that the maximum heat transfer rate occurred at the evaporator temperature of $150^{\circ} \mathrm{C}$ and an angle range of $70-80^{\circ}$ with respect to the horizontal. Most of the earlier research assumed PHP to be straight tube and did not consider bends. K. R. Narasimha et al. [10] studied the liquid slug velocity in PHP considering it to be function of different parameters. They solved the governing equations of PHP applying Runge-Kutta method. The results showed that for a lower FR, higher diameter and a high difference in temperature between evaporator and condenser resulted in higher slug velocities. This in turn caused higher momentum transfer resulting greater heat transfer.

Mauro M. et al. [11] widened the research on PHP by considering the impact of bends as well. They proposed theoretical model of CLPHP and tested its response by fluctuating three parameters: no. of turns( 3,9 \& 39), heat flux and inclination angle. The authors observed that the simulated model with 3 turns could only operate in bottom heat mode. In case of the CLPHP with nine turns it was observed that it could operate in horizontal position as well, although with a lower thermal performance. Also it was noted that numerical results for PHP with 39 turns, operating in the Bottom Heat Mode, reflected the qualitative experimental trends. Peng Cheng and Hongbin Ma [12] performed mathematical modeling of CLPHP capable of predicting the oscillatory motion of its working fluid by assuming it as a spring-mass system. The model predicted that as the number of 
turns increased, the difference in temperature between the evaporator and the condenser $(\Delta \mathrm{T})$ required to start the oscillating motion decreased. The authors found that liquid slugs' average velocity depended on $\Delta \mathrm{T}$ of the PHP and increasing the number of bubbles made the system more unstable but easy to start up. S. Zinna et al. [13] proposed a numerical model of CLPHP which considered the impact of the local pressure losses on its performance due to thex meanderings which have been neglected by many models. They found that particularly for the horizontal mode and for high heat input levels, the local pressure losses due to bends and turns had a significant impact on the device operation. Sejung K. et al. [14] studied the thermal behavior of a U-shaped PHP (modeled as straight pipe) with fluctuation of evaporator and condenser section temperatures. They observed that increase in amplitude and the frequency of fluctuation of the temperature of the wall resulted decrease in the frequency of oscillation of liquid slug.

D. Yin et al. [15] developed a model capable of predicting the impact of the FR on the power required for start-up of a PHP having one turn. It was observed that the heat input required to initiate the oscillatory motion of the working fluid within the PHP increased when the FR was increased. The model also predicted that there is an upper limit of FR above which the PHP cannot start up with the oscillatory movement of working fluid even though the heat flux becomes considerably high. It was observed that for the given PHP, when charged with water and ethanol, the upper limits were $76.2 \%$ and $78.6 \%$ respectively, at an operating temperature of 335K. A. A.van Steenhovenet al. [16] developed a one dimensional mass-spring-damper system to study the motion of fluid in a CLPHP. It was observed increasing the heat input resulted caused the translational and combined oscillatory- translational motion to become dominant, thus increasing its thermal performance. B. Mehta [17] developed models of PHP to predict its thermal performance based on Artificial Neural Network and Regression / Correlation Analysis (RCA) approach using literature-based dataset. A Coefficient Of Determination abbreviated as $\mathrm{R}^{2}$ of 0.89 which affirms good agreement with higher prediction accuracy was found for the model developed based on feed-forward back-propagation ANN, while the RCA model was not observed to be in agreement with $\mathrm{R}^{2}=0.38$.

\section{Numerical Simulations Using CFD}

Y Hao et al. [18] successfully simulated the flow of working fluid in a CLPHP by developing a mathematical model considering the impact of surface tension and vapor-liquid interface on the vapor-liquid multi-phase flow. The Fluent 6.1, a commercial CFD code, using VOF method, was applied for simulation. Subhash $\mathrm{N}$ et. al, [19] successfully simulated behavior of a vapor bubble generated in an evaporator and its oscillation due to the pressure difference, observed during two phase flow in a CLPHP. It was proved that the heat transfer takes place due to oscillation of liquid plug and vapor slug. The Star CCM+ using VOF model was selected for the study. Zirong L. et al. [20] presented a mathematical and physical model of Micro-OPHP (MOHP). VOF and a mixture model were successfully used to perform simulation of the multi phase flow and transfer of heat in a PHP. FLUENT was used for simulation. It was observed that as compared to the heat transfer lengths as variable, the ID had a higher influence on the performance of MOHPs. Rudresha S. and Vijee Kumar [21] made a successful attempt to augment the heat transfer of CLPHP by employing $\mathrm{SiO}_{2} /$ DI water and $\mathrm{Al}_{2} \mathrm{O}_{3}$ / DI water nanofluids as working fluid in an experimental setup followed by CFD analysis. Validation of CFD results with experimental data was successfully achieved. P R. Pachghare et al. [22], experimentally investigated performance of copper CLPHP with water, ethanol, methanol and acetone as working fluids.They also investigated PHP with different the binary mixtures. This was followed by successful simulation of the volume of fluid (VOF) based PHP model in STAR CCM+.

He Ma et al. [23] made use of VOF method to study the impact of ratio of the length of evaporator to that of the condenser on the start-up behavior and heat transfer characteristics of CLPHP. It was found that reducing the length of condenser within a suitable range resulted acceleration of the start-up process and caused decrease in the thermal resistance, at the same filling ratio and input power condition, while the dry-out occurred easily at low filling ratio. Mohd Aijaz ul Haque et al. [24] successfully simulated single loop PHP using acetone as working fluid in FLUENT. The PHP exhibited better thermal performance at a FR of 60\%. Hao Zhu et al. [25] implemented simulation of single turn CLPHP at three vacuum degrees to analyze the relationship of flow pattern distribution and pressure distribution through CFD. The authors observed that the different flow distributions was achieved for the different vacuum pressures. J. Venkata suresh et al. [26] successfully performed and validated CFD modeling of two turns PHPs in ANSYS CFX. Two PHPs with different I.D.s of 2 $\mathrm{mm}$ and $3 \mathrm{~mm}$, operating on different binary mixtures for FR of 50\% were investigated. Among the two PHPs, 
the one with inner diameter $2 \mathrm{~mm}$ using water-methanol with 50\% filling ratio gave optimum results. Ashutosh Gupta et al. [27], performed simulation to understand the heat transfer mechanism in CLPHP (with water as a working fluid) and predict its performance in vertical position, agreeing with the experimental data. They took into consideration the impact of phase change using Lee model and surface tension using continuum surface model.

\section{EXPERIMENTAL INVESTIGATIONS}

The behavior of PHP is affected by a variety of parameters viz. Inner Diameter (I.D.), Fill Ratio (FR), PHP Configuration, Inclination Angle $\left(\Theta^{\circ}\right)$, Number of Turns (n), length of Evaporator $\left(\mathrm{L}_{\mathrm{e}}\right)$ and Condenser $\left(\mathrm{L}_{\mathrm{c}}\right)$ and Working Fluid Properties. Effects of these parameters have been studied experimentally by many investigators across the globe. Table 1 summarizes some of the latest experimental investigations. The subsequent sections deal with conclusion of experimental investigations done by various researchers to study influence of above parameters.

\section{Impact of Flow Channel Dimensions}

The flow channel dimension is a primary design parameter affecting the PHP system dynamics. Most of the experimental works have been performed on PHP of cross section of circular shape. Its internal diameter has a substantial influence on the flow characteristics of the working fluid which is fundamentally important for its function and thermal performance. For a tube with circular cross-section, the 'pulsating' mode in the flow is achieved only up to a definite diameter, which can be tentatively determined by the critical Bond number (or Eötvös) criterion [28], given by equation (2),

$$
(\mathrm{EÖ})=(\mathrm{Bo})^{2} \approx \frac{\mathrm{D}_{\mathrm{crit}}^{2} \cdot \mathrm{g} \cdot\left(\rho_{\mathrm{liq}}-\rho_{\mathrm{vap}}\right)}{\sigma}
$$

It is observed that the critical heat flux and critical temperature that represent the operation limit of CLPHP increases with increase in diameter, when check valves are installed on it [29]. The thermal resistance of CLPHP decreases for both the vertical as well as horizontal orientation as the flow channel diameter increases [30,31]. Influence of a varying diameter channel (dual diameter) on the flow characteristics and the thermal performance characteristics of a PHP have been investigated. It is noted that the dual diameter PHP have significantly lesser thermal resistance in comparison with the conventional one with single diameter [32].

Table 1. Summary of Recent Experimental Investigations

\begin{tabular}{|c|c|c|c|l|l|}
\hline Reference & $\begin{array}{c}\text { PHP } \\
\text { Type }\end{array}$ & Turns & $\begin{array}{c}\text { Working } \\
\text { fluid }\end{array}$ & $\begin{array}{c}\text { Special } \\
\text { Feature }\end{array}$ & \multicolumn{1}{|c|}{ Conclusions } \\
\hline$[30]$ & CLPHP & 32 & $\begin{array}{c}\text { R123, } \\
\text { ethanol, and } \\
\text { water }\end{array}$ & $\begin{array}{l}\text { PHP with } \\
\text { refrigerant as } \\
\text { working } \\
\text { fluid was } \\
\text { tested }\end{array}$ & $\begin{array}{l}\text { The thermal performance increases for } \\
\text { CLPHP as the ID increases. }\end{array}$ \\
\hline$[31]$ & CLPHP & 6 & Ethanol & & $\begin{array}{l}\text { PHP operates in pulsating mode for a } \\
\text { diameter up less than 2.5 mm. }\end{array}$ \\
\hline$[32]$ & CLPHP & 1 & Ethanol & $\begin{array}{l}\text { Dual dia- } \\
\text { meter PHP } \\
\text { tested }\end{array}$ & $\begin{array}{l}\text { Use of dual-diameter helps reduce } \\
\text { thermal resistance by 45\%. }\end{array}$ \\
\hline$[33]$ & CLPHP & 3 turns & $\begin{array}{c}\text { Ethanol and } \\
\text { Acetone }\end{array}$ & & $\begin{array}{l}\text { Optimum results obtained for acetone at } \\
60 \% \text { fill ratio with a heat load of 50 } \\
\text { watts, while for ethanol at 50\% filling } \\
\text { ratio with a heat load of 75W. }\end{array}$ \\
\hline
\end{tabular}


Table 1. Continued

\begin{tabular}{|c|c|c|c|c|c|}
\hline Reference & $\begin{array}{l}\text { PHP } \\
\text { Type }\end{array}$ & Turns & $\begin{array}{l}\text { Working } \\
\text { fluid }\end{array}$ & $\begin{array}{l}\text { Special } \\
\text { Feature }\end{array}$ & Conclusions \\
\hline [34] & CLPHP & $\begin{array}{c}15,25,35 \\
, 45\end{array}$ & Methanol & $\begin{array}{l}\text { Condenser } \\
\text { below } \\
\text { evaporator } \\
\text { position } \\
\text { tested }\end{array}$ & $\begin{array}{l}\text { 1. A larger temperature fluctuation } \\
\text { amplitude and lower temperature level } \\
\text { appear for higher no. of turns. } \\
\text { 2. } \mathrm{R}_{\mathrm{th}} \text { first increases (from } 50 \% \text { to } 70 \% \text { ) } \\
\text { after which it decreases (from } 70 \% \text { to } \\
80 \% \text { ), as FR increases. }\end{array}$ \\
\hline [35] & CLPHP & 17 & Ethanol & $\begin{array}{l}\text { PHP with } \\
\text { Square c/s } \\
\text { tested }\end{array}$ & $\begin{array}{l}\text { PHP with circular c/s performs better } \\
\text { than that with square one and lowest } \\
\text { thermal resistance observed at } 60 \% \text {. }\end{array}$ \\
\hline [36] & CLPHP & 2 & $\begin{array}{l}\text { Water \& } \\
\text { Ethanol }\end{array}$ & & $\begin{array}{l}\text { Thermal resistance decreases with } \\
\text { increasing heat input }\end{array}$ \\
\hline [37] & CLPHP & 16 & $\begin{array}{l}\text { Water and } \\
\text { ethanol }\end{array}$ & & $\begin{array}{l}\text { Maximum heat load is dependent on FR } \\
\text { while start-up heat load is not. }\end{array}$ \\
\hline [38] & CLPHP & 10 & $\begin{array}{l}\text { DI water, } \\
\text { methanol, } \\
\text { ethanol and } \\
\text { acetone }\end{array}$ & $\begin{array}{l}\text { Effect of } \\
\text { liquid } \\
\text { specific } \\
\text { heat and } \\
\text { LHV tested }\end{array}$ & $\begin{array}{l}\text { 1) Higher LHV was favorable for the heat } \\
\text { transfer at heat input of higher value. } \\
\text { 2) Boiling point and LHV of lower value } \\
\text { lead to ease in dry out. }\end{array}$ \\
\hline [39] & CLPHP & 5 & $\begin{array}{l}\text { Water, } \\
\text { methanol, } \\
\text { ethanol \& } \\
\text { acetone }\end{array}$ & & $\begin{array}{l}\text { Thermal resistances for different working } \\
\text { fluids and different FRs tended to come } \\
\text { closer to one another, under great heat } \\
\text { input (e.g. } 65 \mathrm{~W} \text { ). }\end{array}$ \\
\hline [40] & CLPHP & 1 & $\begin{array}{l}\text { Distilled } \\
\text { water }\end{array}$ & $\begin{array}{l}\text { Flow } \\
\text { Visuali- } \\
\text { zation } \\
\text { technique } \\
\text { applied }\end{array}$ & $\begin{array}{l}\text { There exists an optimal } \\
\text { FR (within } 40-50 \% \text { ) and an optimal } \\
\text { inclination angle (within } 50^{\circ}-70^{\circ} \text { ) for } \\
\text { which the PHP offered the best } \\
\text { performance. }\end{array}$ \\
\hline [41] & CLPHP & 31 & FC-72 & & $\begin{array}{l}\text { Gravity has a significant impact on } \\
\text { CLPHP and the optimal FR is } 0.5 \text {. }\end{array}$ \\
\hline [42] & CLPHP & 4 & Helium & $\begin{array}{l}\text { Cryogenic } \\
\text { PHP } \\
\text { investi- } \\
\text { gated }\end{array}$ & $\begin{array}{l}\text { For the PHP at more than } 30^{\circ} \\
\text { inclination and FR of } 70.8 \% \text {, the effective } \\
\text { thermal conductivity ranged from } 4800- \\
13,000 \mathrm{~W} / \mathrm{m} \mathrm{K}\end{array}$ \\
\hline [43] & CLPHP & 5 & $\begin{array}{l}\text { DI water and } \\
\text { CTAB } \\
\text { solution with } \\
\text { DI water }\end{array}$ & $\begin{array}{l}\text { Effect of } \\
\text { CTAB } \\
\text { surfactant } \\
\text { explored }\end{array}$ & $\begin{array}{l}\text { When FR is } 50 \% \text {, the } \mathrm{R}_{\mathrm{th}} \text { of PHP with } \\
\text { surfactant decreased by } 48.5 \% \text { at the } \\
\text { input power of } 100 \mathrm{~W} \text { as compared to that } \\
\text { with plain water }\end{array}$ \\
\hline [44] & CLPHP & $\begin{array}{c}6,11 \text { and } \\
18\end{array}$ & Nitrogen & $\begin{array}{l}\text { Test Con- } \\
\text { ducted } 75 \\
\text { and } 90 \mathrm{~K}\end{array}$ & $\begin{array}{l}\text { Increasing the number of parallel } \\
\text { channels results in longer oscillating } \\
\text { phase and better thermal performances. }\end{array}$ \\
\hline [45] & CLPHP & $\begin{array}{l}11,22 \\
\text { and } 33\end{array}$ & $\begin{array}{l}\text { R123, and } \\
\text { ethanol }\end{array}$ & $\begin{array}{l}\text { Rotating } \\
\text { CLPHP } \\
\text { tested }\end{array}$ & $\begin{array}{l}\text { With increase in centrifugal acceleration, } \\
\text { there is decrease in } R_{\text {th }} \text { per unit area. }\end{array}$ \\
\hline
\end{tabular}


Journal of Thermal Engineering, Review Article, Vol. 7, No. 3, pp. 387-408, March, 2021

Table 1. Continued

\begin{tabular}{|c|c|c|c|c|c|}
\hline Reference & $\begin{array}{l}\text { PHP } \\
\text { Type }\end{array}$ & Turns & $\begin{array}{c}\text { Working } \\
\text { fluid }\end{array}$ & Special Feature & Conclusions \\
\hline [46] & CLPHP & 20 & Nitrogen & $\begin{array}{l}\text { PHP consists } \\
\text { of } 40 \text { parallel } \\
\text { tubes. }\end{array}$ & $\begin{array}{l}\text { Even with a high number of turns, gravity } \\
\text { has a noteworthy effect on the PHP's } \\
\text { thermal performance. }\end{array}$ \\
\hline [47] & CLPHP & 1 & Water & $\begin{array}{l}\text { PHP with } \\
\text { Tesla valves } \\
\text { explored }\end{array}$ & $\begin{array}{l}\text { PHP with Tesla valves resulted in a } \\
\text { decrease of thermal resistance of around } \\
14 \% \text {, when compared with the one without } \\
\text { valves. }\end{array}$ \\
\hline [48] & CLPHP & 10 & DI water & $\begin{array}{l}\text { CLPHP with } \\
\text { check-valve } \\
\text { tested }\end{array}$ & $\begin{array}{l}\text { Addition of the check valve in PHP } \\
\text { decreases the start-up temperature and } \\
\text { thereby improves its thermal performance. }\end{array}$ \\
\hline [49] & CLPHP & 20 & $\mathrm{R} 152 \mathrm{a}$ & $\begin{array}{l}\text { PHP with } \\
\text { capillary } \\
\text { barriers (CBs) } \\
\text { and with ball } \\
\text { check-valves } \\
\text { tested }\end{array}$ & $\begin{array}{l}\text { 1. Directional circulation of a working } \\
\text { fluid was obtained for PHP with BCVs } \\
\text { along with increase in limiting heat loads } \\
\text { by } 10-14 \% \text {. } \\
\text { 2.CBs used in PHPs were found to } \\
\text { ineffective }\end{array}$ \\
\hline [50] & CLPHP & 30 & R134a & $\begin{array}{l}\text { Double- } \\
\text { Condenser } \\
\text { (DCPHP) \& } \\
\text { single- } \\
\text { condenser PHP } \\
\text { (SCPHP) } \\
\text { tested }\end{array}$ & $\begin{array}{l}\text { 1. DCPHP has lower Rth than SCPHP (up } \\
\text { to } 66 \% \text { ) } \\
\text { 2. DCPHP can handle around four times } \\
\text { higher maximum allowable input power } \\
\text { compared to the SCPHP }\end{array}$ \\
\hline [51] & CLPHP & $\begin{array}{c}1 \text { and } \\
2\end{array}$ & $\begin{array}{l}\text { Ethanol } \\
\text { and DI } \\
\text { Water }\end{array}$ & $\begin{array}{l}1 \text { turn Parallel } \\
\text { connected PHP } \\
\text { tested }\end{array}$ & $\begin{array}{l}\text { Parallel connected PHP shows better } \\
\text { thermal performance at high input power } \\
\text { compared to two turns PHP. }\end{array}$ \\
\hline [52] & OLPHP & 8 & $\begin{array}{l}\text { Methanol } \\
\text { and } \\
\text { Ethanol }\end{array}$ & $\begin{array}{l}\text { OLPHP with } \\
\text { copper wire } \\
\text { insert tested }\end{array}$ & $\begin{array}{l}\text { 1. Compared to ethanol, methanol was } \\
\text { found to be the superior working fluid. } \\
\text { 2. PHP operated with better thermal } \\
\text { performance at } 45^{\circ} \text { orientation. }\end{array}$ \\
\hline [53] & CLPHP & 4 & $\begin{array}{l}\text { Water, } \\
\text { methanol } \\
\text { and HFE- } \\
7100\end{array}$ & $\begin{array}{l}\text { Alternating } \\
\text { tube diameter } \\
\text { PHP tested }\end{array}$ & $\begin{array}{l}\text { It was found that alternating diameter PHP } \\
\text { was capable of starting at a lower heat } \\
\text { input leading to much smaller } \mathrm{R}_{\mathrm{th}} \text { when } \\
\text { compared to that of the uniform design. }\end{array}$ \\
\hline [54] & CLPHP & 4 & $\begin{array}{l}\text { Water and } \\
\text { HFE-7000 }\end{array}$ & $\begin{array}{l}\text { Impact of } \\
\text { evacuation } \\
\text { pressure } \\
\text { investigated. }\end{array}$ & $\begin{array}{l}\text { Authors implied that the evacuation } \\
\text { pressure imposes quite different influences } \\
\text { on the performance of PHPs depending } \\
\text { upon the working fluid used. }\end{array}$ \\
\hline [55] & CLPHP & 5 & $\begin{array}{l}\text { Distilled } \\
\text { water }\end{array}$ & $\begin{array}{l}\text { PHP with } \\
\text { Super- } \\
\text { hydrophobic } \\
\text { Channels } \\
\text { tested }\end{array}$ & $\begin{array}{l}\text { The } \mathrm{R}_{\mathrm{th}} \text { of the PHP with Super- } \\
\text { hydrophobic Channel was higher than the } \\
\text { one with hydrophilic channel. }\end{array}$ \\
\hline
\end{tabular}


Table 1. Continued

\begin{tabular}{|c|c|c|c|c|c|}
\hline Reference & $\begin{array}{l}\text { PHP } \\
\text { Type }\end{array}$ & Turns & $\begin{array}{c}\text { Working } \\
\text { fluid }\end{array}$ & $\begin{array}{l}\text { Special } \\
\text { Feature }\end{array}$ & Conclusions \\
\hline$[56]$ & CLPHP & 2 & Ethanol & $\begin{array}{l}\text { Flexible, } \\
\text { light-weight } \\
\text { and low cost } \\
\text { polypropy- } \\
\text { lene PHP } \\
\text { tested }\end{array}$ & $\begin{array}{l}\text { Results showed nearly three times } \\
\text { increase in the effective thermal } \\
\text { conductance of the Polypropylene PHP } \\
\text { in comparison to that of the material } \\
\text { forming its envelope. }\end{array}$ \\
\hline [57] & CLPHP & 3 & FC-72 & $\begin{array}{l}\text { Flexible PHP } \\
\text { tested }\end{array}$ & $\begin{array}{l}\text { The performance of the bent PHS was } \\
20 \% \text { to } 40 \% \text { less in comparison to the } \\
\text { straight vertical PHS. }\end{array}$ \\
\hline$[58]$ & CLPHP & 5 & FC-72 & $\begin{array}{l}\text { PHP tested in } \\
\text { micro- } \\
\text { gravity }\end{array}$ & $\begin{array}{l}\text { PHP operate as thermosyphon for in } \\
\text { both vertical position as well as } \\
\text { Horizontal position in Microgravity. }\end{array}$ \\
\hline [59] & CLPHP & 1 & Water & $\begin{array}{l}\text { PHP with } \\
\text { additional } \\
\text { branch } \\
\text { tested. }\end{array}$ & $\begin{array}{l}\text { PHP with additional branch exhibited } \\
\text { improved thermal performance against } \\
\text { conventional pulsating heat } \\
\text { pipes. }\end{array}$ \\
\hline$[60]$ & CLPHP & 6 & $\begin{array}{l}\mathrm{Al}_{2} \mathrm{O}_{3} \\
\text { nanofluid } \\
\text { with water } \\
\text { as base } \\
\text { fluid. }\end{array}$ & $\begin{array}{l}\text { Nano-fluid } \\
\text { explored }\end{array}$ & $\begin{array}{l}\text { Greatest decrease in } \mathrm{R}_{\text {th }} \text { was observed } \\
\text { for PHP with } 1.0 \% \text { nanofluid } \\
\text { concentration by weight at } 45^{\circ} \\
\text { inclination, in comparison to that for } \\
\text { PHP with DI water. }\end{array}$ \\
\hline$[61]$ & OLPHP & 8 & Methanol & $\begin{array}{l}\text { OLPHP } \\
\text { having } \\
\text { Condenser } \\
\text { with fin } \\
\text { explored }\end{array}$ & $\begin{array}{l}\text { Finned OLPHP at } 45^{\circ} \text { inclination } \\
\text { displayed substantial enhancement of } \\
\text { heat transfer in comparison with that of } \\
\text { OLPHP with no fins. }\end{array}$ \\
\hline$[62]$ & CLPHP & 8 & Methanol & $\begin{array}{l}\text { CLPHP } \\
\text { having } \\
\text { Condenser } \\
\text { with fin } \\
\text { explored } \\
\end{array}$ & $\begin{array}{l}\text { Finned CLPHP at } 45^{\circ} \text { inclination } \\
\text { displayed substantial heat transfer } \\
\text { enhancement in } \\
\text { comparison with that of CLPHP without } \\
\text { fin }\end{array}$ \\
\hline$[63]$ & CLPHP & 13 & $\begin{array}{c}\text { Water and } \\
\text { Ethanol }\end{array}$ & & $\begin{array}{l}\text { 1. PHP performs better at } 60^{\circ} \text { to } 75^{\circ} \\
\text { inclination than other position } \\
\text { 2. Compared to ethanol, Water is found } \\
\text { to be a better working fluid. }\end{array}$ \\
\hline [64] & CLPHP & 6 & Ammonia & & $\begin{array}{l}\text { 1. } \mathrm{R}_{\text {th }} \text { decreases with the increase in } \\
\text { inclination angle. } \\
\text { 2. The best filling ratio to be from } 70 \% \\
\text { to } 80 \% \text { to prevent burnout. }\end{array}$ \\
\hline$[65]$ & OLPHP & 5 & $\begin{array}{l}\text { Nanofluid } \\
\text { with } \\
\left(\mathrm{NH}_{2}\right)_{2} \mathrm{CO} \\
\text { as } \\
\text { surfactant }\end{array}$ & $\begin{array}{l}\text { Magnetic } \\
\text { nanofluids } \\
\text { with } \\
\text { surfactant } \\
\text { tested }\end{array}$ & $\begin{array}{l}\text { Application of a magnetic field reduces } \\
\text { the } R_{\text {th }} \text { and the most excellent thermal } \\
\text { performance was observed for } \\
\text { inclination of } 67.5^{\circ} \text {. }\end{array}$ \\
\hline [66] & $\begin{array}{l}\text { CLM- } \\
\text { PHP \& } \\
\text { CEM- } \\
\text { PHP }\end{array}$ & $\begin{array}{l}5,10 \\
15, \text { and } \\
20 \\
\text { turns }\end{array}$ & Ethanol & $\begin{array}{l}\text { Micro } \\
\text { Pulsating } \\
\text { Heat pipes } \\
\text { (MPHPs) } \\
\text { tested. }\end{array}$ & $\begin{array}{l}\text { It was concluded for CEMPHP and } \\
\text { CLMPHP required } 10 \text { and } 20 \text { turns } \\
\text { respectively to ensure orientation- } \\
\text { independent performance }\end{array}$ \\
\hline
\end{tabular}


Journal of Thermal Engineering, Review Article, Vol. 7, No. 3, pp. 387-408, March, 2021

Table 1. Continued

\begin{tabular}{|c|c|c|c|c|c|}
\hline Reference & $\begin{array}{l}\text { PHP } \\
\text { Type }\end{array}$ & Turns & $\begin{array}{c}\text { Working } \\
\text { fluid }\end{array}$ & $\begin{array}{l}\text { Special } \\
\text { Feature }\end{array}$ & Conclusions \\
\hline [67] & CLPHP & 12 & HFE-7000 & $\begin{array}{l}\text { Flexible } \\
\text { pulsating } \\
\text { heat pipe } \\
\text { (FPHP) } \\
\text { tested }\end{array}$ & $\begin{array}{l}\text { The } \mathrm{R}_{\mathrm{th}} \text { of FPHP was found to be } 2.41 \\
\mathrm{~K} / \mathrm{W} \text {, for vertical orientation, which is } \\
37 \% \text { lesser than that of the copper } \\
\text { sample taken as reference. }\end{array}$ \\
\hline [68] & OLPHP & $\begin{array}{c}20 \text { and } \\
40\end{array}$ & $\begin{array}{l}\text { Acetone, } \\
\text { Ethanol, } \\
\text { Pentane and } \\
\text { Water }\end{array}$ & $\begin{array}{l}\text { Evaporator } \\
\text { on top } \\
\text { position } \\
\text { tested }\end{array}$ & $\begin{array}{l}\text { 1. } \mathrm{R}_{\mathrm{th}} \text { decreases with increasing heat } \\
\text { input. } \\
\text { 2. Vertical orientation leads to lower } \\
\mathrm{R}_{\mathrm{th}} \text { than horizontal. }\end{array}$ \\
\hline [69] & CLPHP & 12 & R134a & & $\begin{array}{l}\text { Results point out that optimum filling } \\
\text { ratio for highest thermal performance } \\
\text { is around } 40-50 \% \text { in spite of any } \\
\text { adiabatic length. }\end{array}$ \\
\hline [70] & CLPHP & 5 & Hydrogen & $\begin{array}{l}\text { Long PHP } \\
\text { tested }\end{array}$ & $\begin{array}{l}\text { 1. } \mathrm{R}_{\mathrm{th}} \text { of the PHP with } 500 \mathrm{~mm} \\
\text { adiabatic section was } 30 \% \text { more than } \\
\text { the other PHP. } \\
\text { 2. The longer PHP has a superior heat } \\
\text { transfer limit and has a more stable } \\
\text { thermal performance. }\end{array}$ \\
\hline [71] & CLPHP & 5 & $\begin{array}{l}\text { DI water \& } \\
\text { iron oxide } \\
\text { nanofluid }\end{array}$ & $\begin{array}{l}\text { Magnetic } \\
\text { nanofluid } \\
\text { tested }\end{array}$ & $\begin{array}{l}\text { Improvement in the performance of the } \\
\text { CLPHP is observed with use of a } \\
\text { magnetic nanofluids and magnetic } \\
\text { field. }\end{array}$ \\
\hline [72] & CLPHP & 5 & $\begin{array}{l}\text { Ethanol- } \\
\text { water, } \\
\text { Ethanol- } \\
\text { methanol } \\
\text { and } \\
\text { Ethanol- } \\
\text { acetone }\end{array}$ & $\begin{array}{l}\text { Mixed } \\
\text { working } \\
\text { tested }\end{array}$ & $\begin{array}{l}\text { For low FRs viz. } 45 \% \text { and } 55 \% \text {, mixed } \\
\text { working fluid was found to be } \\
\text { favorable for the operation of PHP } \\
\text { with the } \mathrm{R}_{\text {th }} \text { lower than that charged } \\
\text { with pure ethanol or water but this was } \\
\text { vice versa for higher FRs }(62 \%, 70 \% \text {, } \\
90 \%) \text {. }\end{array}$ \\
\hline [73] & CLPHP & 7 & $\begin{array}{l}\text { R134a, R22 } \\
\text { and R600a }\end{array}$ & $\begin{array}{l}\text { Refriger- } \\
\text { ant tested }\end{array}$ & $\begin{array}{l}\text { PHP with R22 offers least Resistance } \\
\text { as compared to PHP with other two } \\
\text { fluids }\end{array}$ \\
\hline [74] & $\begin{array}{l}\text { CLPHP } \\
\text { with } \\
\text { copper } \\
\text { wire } \\
\text { inserts } \\
\end{array}$ & 8 & $\begin{array}{l}\text { Methanol } \\
\text { and Ethanol }\end{array}$ & $\begin{array}{l}\text { CLPHP } \\
\text { with copper } \\
\text { wire inserts } \\
\text { tested }\end{array}$ & $\begin{array}{l}\text { Methanol was found to be the best } \\
\text { working fluid for PHP than ethanol for } \\
\text { a broad range of heat inputs. }\end{array}$ \\
\hline [75] & CLPHP & †ो十 & $\begin{array}{l}\text { C60 } \\
\text { nano- } \\
\text { particles in } \\
\text { Ethanol }\end{array}$ & $\begin{array}{l}\text { C60 } \\
\text { nanofluid } \\
\text { investigated }\end{array}$ & $\begin{array}{l}\text { Increasing concentration of } \mathrm{C} 60 \\
\text { improved the thermal performance of } \\
\text { heat pipe but causing reduction in } \\
\text { critical heat load. }\end{array}$ \\
\hline
\end{tabular}

†† Details not given 
Table 1. Continued

\begin{tabular}{|c|c|c|c|c|c|}
\hline Reference & $\begin{array}{l}\text { PHP } \\
\text { Type }\end{array}$ & Turns & $\begin{array}{l}\text { Working } \\
\text { fluid }\end{array}$ & Special Feature & Conclusions \\
\hline [76] & CLPHP & 10 & $\begin{array}{l}\text { Ethanol, } \\
\text { acetone, } \\
\text { water, } \\
\text { methanol } \\
\text { and binary } \\
\text { mixtures }\end{array}$ & $\begin{array}{l}\text { Binary } \\
\text { mixtures } \\
\text { explored }\end{array}$ & $\begin{array}{l}\text { 1.Pure acetone provided best } \\
\text { performance in PHP, in contrast to the } \\
\text { other working fluid. } \\
\text { 2. For Binary mixture, water-methanol } \\
\text { gave best thermal performance } \\
\text { compared to the other working fluid. }\end{array}$ \\
\hline [77] & OLPHP & 5 & $\begin{array}{l}\text { Water and } \\
\text { ferrofluid } \\
(1.25,2.5, \\
\text { and } 5 \mathrm{~g} / \mathrm{L} \\
\text { concentratio } \\
\text { n) }\end{array}$ & $\begin{array}{l}\text { Ferrofluid as } \\
\text { working fluid } \\
\text { is tested. }\end{array}$ & $\begin{array}{l}\text { 1. Use of ferrofluid and magnetic field } \\
\text { improved the thermal performance } \\
2.2 .5 \mathrm{~g} / \mathrm{L} \text { was the optimal } \\
\text { concentration of ferrofluid for steady } \\
\text { state condition. }\end{array}$ \\
\hline [78] & CLPHP & 5 & $\begin{array}{l}\text { DI water, } \mathrm{Ag} \\
\text { and } \mathrm{Cu} \\
\text { nanofluids }\end{array}$ & $\begin{array}{l}\text { PHP using } \\
\text { Nanofluid } \\
\text { tested }\end{array}$ & $\begin{array}{l}\text { The heat transfer limit was enhanced } \\
\text { by } 33.3 \% \text { in case of nanofluid charged } \\
\text { PHP. }\end{array}$ \\
\hline [79] & CLPHP & 5 & $\begin{array}{l}\text { Pure water } \\
\text { and hydr- } \\
\text { oxylated } \\
\text { MWNTs } \\
\text { nanofluids }\end{array}$ & $\begin{array}{l}\text { PHP using } \\
\text { Nanofluid } \\
\text { tested }\end{array}$ & $\begin{array}{l}\text { The } \mathrm{R}_{\text {th }} \text { of PHP with } 0.1 \mathrm{wt} \% \text { nanofluid } \\
\text { is reduced by } 34 \% \text { as contrast to PHP } \\
\text { with water PHP. }\end{array}$ \\
\hline [80] & CLPHP & 2 & $\begin{array}{c}\text { Graphene } \\
\text { oxide } \\
\text { nanofluid }\end{array}$ & $\begin{array}{l}\text { Nano-fluid } \\
\text { explored }\end{array}$ & $\begin{array}{l}\text { High concentration of the nanofluid } \\
(1.5 \mathrm{~g} / \text { lit }) \text { worsens the thermal } \\
\text { performance of PHP }\end{array}$ \\
\hline [81] & CLPHP & 5 & $\begin{array}{l}\text { Acetone, } \\
\text { Methanol, } \\
\text { Ethanol and } \\
\text { Heptane } \\
\end{array}$ & $\begin{array}{l}\text { Analysis } \\
\text { focused on } \\
\text { dimension-less } \\
\text { numbers. } \\
\end{array}$ & $\begin{array}{l}\text { Acetone gave best performance as } \\
\text { contrast to rest of the working fluids. }\end{array}$ \\
\hline [82] & CLPHP & 5 & $\begin{array}{c}\text { Water } \\
\text { acetone } \\
\text { mixtures }\end{array}$ & & $\begin{array}{l}\text { Mixing a fraction of water with pure } \\
\text { acetone was better in preventing early } \\
\text { start of dry-out, but mixing a fraction } \\
\text { of pure acetone with water failed at } \\
\text { preventing onset of dry-out. }\end{array}$ \\
\hline [83] & CLPHP & 5 & FC-72 & $\begin{array}{l}\text { A hybrid } \\
\text { Thermo- } \\
\text { syphon/CLPH } \\
\mathrm{P} \text { with an I.D. } \\
\text { more than the } \\
\text { capillary } \\
\text { dimension }\end{array}$ & $\begin{array}{l}\text { 1. Device operates as a Multi- } \\
\text { Evaporator type Loop Thermo-syphon } \\
\text { on ground condition with an } \\
\text { enhancement in thermal performance } \\
\text { for non-uniform heating } \\
\text { configurations. } \\
\text { 2. Nonexistence of the buoyant effect } \\
\text { in microgravity condition leads to PHP } \\
\text { oscillating flow in the device. }\end{array}$ \\
\hline [84] & CLPHP & 2 & $\begin{array}{l}\text { Ethanol and } \\
\text { Mixture of } \\
\text { ethanol \& } \\
\text { water }\end{array}$ & $\begin{array}{l}\text { Thermal- } \\
\text { hydraulic } \\
\text { performance } \\
\text { explored }\end{array}$ & $\begin{array}{l}\text { A stable operation of the PHP device } \\
\text { was achieved when a circulatory flow } \\
\text { is achieved and superimposed on local } \\
\text { pulsating flow. }\end{array}$ \\
\hline
\end{tabular}


Table 1. Continued

\begin{tabular}{|c|c|c|c|c|c|}
\hline Reference & $\begin{array}{l}\text { PHP } \\
\text { Type }\end{array}$ & Turns & $\begin{array}{l}\text { Working } \\
\text { fluid }\end{array}$ & Special Feature & Conclusions \\
\hline [85] & CLPHP & 6 & Ammonia & $\begin{array}{l}\text { Velocity of the } \\
\text { vapor } \\
\text { experimentally } \\
\text { measured }\end{array}$ & $\begin{array}{l}\text { The fluid velocity is about } 0.1-0.6 \mathrm{~m} / \mathrm{s} \\
\text { when PHP operates at the condition of } \\
\text { "Slug Flow" and is about } 0.4-0.9 \mathrm{~m} / \mathrm{s} \\
\text { when the PHP operates at the condition } \\
\text { of "Annular Flow". }\end{array}$ \\
\hline$[86]$ & CLPHP & 9 & Water & & $\begin{array}{l}\text { The PHP exhibits best performance with } \\
\text { lower FR for same input heat flux. }\end{array}$ \\
\hline [87] & CLPHP & 23 & $\begin{array}{l}\text { Water and } \\
\text { Ethanol }\end{array}$ & $\begin{array}{l}\text { PHP coupled } \\
\text { with synergistic } \\
\text { oscillating PHP } \\
\text { tested }\end{array}$ & $\begin{array}{l}\text { For alike heat source temperature, the } \\
\text { heat transfer by the coupled PHP was } \\
\text { greater than the single PHPs. }\end{array}$ \\
\hline [88] & CLPHP & 9 & Water & & $\begin{array}{l}\text { For the same input of heat, the device } \\
\text { exhibits better performance with low } \\
\text { value of FR. }\end{array}$ \\
\hline [89] & CLPHP & 12 & FC-72 & $\begin{array}{l}\text { Flat Plate } \\
\text { Pulsating Heat } \\
\text { Pipe (FPPHP) } \\
\text { tested }\end{array}$ & $\begin{array}{l}\text { FPPHP can function under microgravity } \\
\text { conditions as well as in a transient } \\
\text { gravity condition, with thermal } \\
\text { resistance in range of } 25 \% \text { to } 50 \% \text { of } \\
\text { that of an empty plate. }\end{array}$ \\
\hline
\end{tabular}

\section{Impact of Filling Ratio}

The filling ratio (FR) also called as charge ratio is defined as the ratio of volume of working fluid present in the PHP to its total volume (flow channel) at a particular temperature (generally room temperature). FR can vary from 0 to $100 \%$ i.e. If FR is $0 \%$ then it represents a device without any working fluid and heat will be transferred from evaporator to condenser purely through conduction. FR $=100 \%$ represents a device having flow channel fully filled with working fluid. The FR has a considerable impact on the heat transfer characteristics of a PHP. Experimental studies have shown that there exists an optimal value of FR for which the $\mathrm{R}_{\mathrm{th}}$ of the PHP loop is minimum [33, 34, 35]. The optimum filling ratio varies with on the working fluids' properties used for a given PHP [36, 37].

It was observed that for the same FR, the PHP with working fluid of boiling point and LHV both of relatively lower values easily undergo dry out even at low input power [38]. It is observed that different FRs leads to different heat input required for triggering oscillatory flow in PHP. The PHP with relatively FRs of smaller values required smaller heat inputs for initiating the flow oscillations [39]. Nandan S. et al. [40] observed that the optimum FR was dependent on orientation.

Mauro M. et al. [41], studied combined impact of the FR and the inclination angle on performance of CLPHP with FC-72 as the working fluid for different heat input levels. The bottom heated PHP with FR $=0.5$ gave the best performance, with thermal resistance five times lower than the empty device. Dong Xu et al. [42] noted that the optimum FR required for maximum heat transfer varied with the heat input for the cryogenic PHP with working fluid as Helium. The FR influences the flow oscillations. For the PHP with lower FRs, it was easier to realize the oscillating motion of the fluid even for a low heat input. In case of the PHP with FRs of higher value, the low input power was not adequate to transfer additional liquid in direction of the condenser section [43].

\section{Impact of Number of Turns}

Number of turns (n) has a strong effect on the heat transfer capabilities of a PHP. Experimental investigations show that more intense temperature fluctuation, leading to better thermal performance at a given heat input could be achieved by increasing the number of parallel channels (turns) of the anti-gravity Pulsating Heat Pipe [34]. Maria Barba et al. [44] found that higher thermal conductivities was achieved with the PHP 
having 36 parallel channels as compared to the one with 22 parallel channels during the oscillating phase. Niti K. et al. [45] also observed decrease in $\mathrm{R}_{\mathrm{th}}$ with increase in number of turns for a Rotating CLPHP. Luis D. F. et al. [46] experimented with PHP consisting of 40 parallel tubes (20 turns) as opposed to nitrogen based cryogenic pulsating heat pipes with 16 parallel tubes ( 8 turns) which is vastly explored. They concluded that even in case of PHP with high number of turns, gravity has a noteworthy effect on its thermal performance.

\section{Impact of Geometry/ Construction}

Besides approaches for enhancing the heat transfer capabilities of PHPs such as using different working fluid, changing the orientation and increasing the number of turns, changes in geometry or construction could also prove to be a noteworthy method. Many researchers have been investigating different techniques which could promote a one-way circulatory flow of the working fluid in a PHP since pause and reversal of flow inexorably occurring in it during its operation hinders the performance. A popular technique is integration of a check valve into a PHP to cause the working fluid to achieve a one-way circulatory flow, which led to improvement in thermal performance of PHPs [47, 48, 49].

Wookyoung K. et al. [50] compared the thermal characteristics of a single-condenser pulsating heat pipe (SCPHP) and a double-condenser pulsating heat pipe (DCPHP), with the later one having up to $60 \%$ lower $\mathrm{R}_{\text {th }}$ than SCPHP. Byeongchan K. et al. [51] performed experiments on parallel connected PHP and two turns PHP, with working fluids as ethanol and deionised water. It was noted that the two turns PHP showed larger thermal resistance than parallel connected PHP for high input power. Other techniques such as use of dualdiameter, alternating tube diameter and use of inserts of wire made of copper and fins added on condensation in pulsating heat pipes have also been established to be favourable in decreasing thermal resistance $[34,52,53]$. Chien-Hung Sun et al. [54], found that evacuation pressure had a substantial impact on the starting characteristics and overall thermal performance of a double tube design type PHP. Luis Betancur et al. [55] explored a novel PHP with alternating superhydrophobic channels concluding that the inner wettability is a very important parameter that needs to be taken into account while designing Oscillating Heat Pipes.

For many of the applications like aerospace, airplane and electronic devices a PHP which is not only lightweight but flexible as well is needed. Flexible PHP made of thermoplastic materials (polypropylene) were investigated and found to be having thermal conductance nearly three times greater than that of the material forming their envelope [56,57]. D. Mangini et al. [58] investigated PHP with a I.D. more than the capillary dimensions in hyper and micro gravity conditions and found it to be working even in horizontal position during micro-gravity period thus illustrating the possibility of use of oscillating heat pipe for space application. E. Sedighi et al. [59] compared conventional PHP with a PHP with an extra branch attached to the evaporator section. This branch acted as a secondary bubble pump and it was observed that the later one has up to $51 \%$ better thermal performance than the former one.

\section{Impact of Inclination Angle}

Experimental results have indicated that heat transfer characteristics of PHP could change with inclination angle especially for the ones with less number of turns. The inclination of PHP alters the way in which in which the working fluid moves thus resulting in different performance levels. Thus, gravity as an vital role during the operation of PHP. Many of the investigations on PHP with 6 to 8 turns point towards substantial enhancement of heat transfer at $45^{\circ}$ inclination $[52,60,61,62]$.

Suchana Akter Jahan et al. [63] observed optimum performance for 13 turns PHP with ethanol and water as working fluid at $75^{\circ}$ inclination with respect to vertical. Xue Zhihu et al. [64] performed visualization investigation on ammonia CLPHP and observed decrease in $\mathrm{R}_{\text {th }}$ with increase in inclination angle. Maziar Mohammadi et al. [65] observed superior thermal performance of Magnetic nanofluid OLPHP at $67.5^{\circ}$ with respect to horizontal. Soohwan Jun et al. [66] compared the thermal performance of closed-loop micro PHP (CLMPHPs) with that of closed-end micro PHP (CEMPHPs). It was observed that the CLMPHP needs atleast 20 turns while for CEMPHP merely 10 turns are sufficient to ensure inclination independent performance. E. Jonghyun Lim et. al [67], proposed Pulsating Heat Pipe made of polymer which is flexible. For vertical orientation the PHP offered thermal resistance of $2.41 \mathrm{~K} / \mathrm{W}$, about $37 \%$ lesser than $\mathrm{R}_{\mathrm{th}}$ of the copper sample taken as reference. The flexible PHP successfully operated in a horizontal orientation in addition to bended conditions. Vincent A. et al. [68], successfully operated a PHP using water for working fluid in vertical unfavourable position i.e. evaporator above the condenser. 


\section{Impact of Length of Evaporator, Adiabatic and Condenser Section}

Complex physics governing the characteristics of PHPs is still very difficult to understand and describe because of many parameters influencing their functioning. The length of flow path could cause a different heat transfer characteristic in a large PHP, which may not be found in a small PHP. Thus, it becomes necessary to identify the impact of length of evaporator, adiabatic and condenser section on the performance of PHP. As far as authors are aware, very few investigations regarding aforesaid issue has hitherto been attempted. Masaru Saijo et al. [69] investigated the impact of adiabatic length and FR of working fluid R134a on thermal characteristics of PHP with check valves. For small FR, the thermal performance was higher with shorter adiabatic length and lower with longer length. In contrast, for high FR, the amount of heat transfer was higher when adiabatic length was longer and lower for shorter length. Zhihua Gan et al. [70] investigated the impact of change in adiabatic length on the heat transfer performance of the CLPHP so as to confirm its ability to transfer heat over a long distance. Two adiabatic section lengths viz.100 and $500 \mathrm{~mm}$ were explored. Hydrogen was the working fluid in both PHPs. The PHP with larger adiabatic length was capable of effectively transporting heat over a long distance but offered higher thermal resistance.

\section{Impact of Input Power}

Heat input to the PHP has a significant effect on its thermal performance since it affects the resulting flow pattern of its working fluid. A common technique to study effect of input power on PHP is to evaluate its Thermal resistances $\left(R_{t h}\right)$ with the increase of heat input. The thermal resistance $\left(R_{t h}\right)$ is mathematically calculated using the below equation:

$$
R_{t h}=\frac{T_{e, a v g}-T_{c, a v g}}{Q}
$$

Where $\mathrm{T}_{\mathrm{e}}$, avg and $\mathrm{T}_{\mathrm{c} \text {, avg }}$ are the average temperatures of evaporator and condenser respectively and $\mathrm{Q}$ is heat rejected to heat reservoir at the condenser. Outcome of the most of the investigations was the reduction in $\mathrm{R}_{\mathrm{th}}$ of the PHP with increasing heat input [36, 39]. For higher heat input, if no dry-out happened, the thermal resistances for different working fluids and different FRs displayed the tendency to come closer to one another. Another technique is to study variation of effective thermal conductivities with heat input [42, 54]. The effective thermal conductivity of a PHP is mathematically given by equation (4) as,

$$
k_{e f f}=\frac{Q \times L_{e f f}}{A \times\left(T_{e, a v g}-T_{c, a v g}\right)}
$$

where $\mathrm{L}_{\mathrm{eff}}$ is the length and $\mathrm{A}$ is the area of heat transfer.

\section{Impact of Working Fluid}

Many investigations have indicated that the thermodynamic and physical properties of the working fluid significantly affect the thermal behavior of the PHPs. Understanding this impact could help in proper selection of the working fluid as per the application. Hua Han et al. [38] investigated effect of dynamic viscosity of the working fluid on the starting characteristics and operation characteristics of CLPHP and also the impact of latent heat of vaporization (LHV) on the operation characteristics by experimenting with water, methanol, ethanol and acetone as the working fluids. The authors found that the dynamic viscosity was the most dominant property affecting the start-up of flow oscillation in the CLPHP than any other properties. They also found that PHP using the working fluid having low boiling point (BP) and low LHV, easily dry out, affirming role of LHV on performance of PHP.

Fariha Mir et al. [52] found methanol to be the superior working fluid in comparison to ethanol for the OLPHP. They concluded that though ethanol has higher BP than methanol the later has higher specific gravity than ethanol inferring that the specific gravity might have dominated the BP. The heat carrying capacity of a working fluids is characterized by properties like specific heat and LHV become dominant during operation mode of PHP. Mohammad Ali, et al. [63] also pointed out that CLPHP with water as working fluid showed better performance in contrast with one with ethanol because of the formers higher normal boiling point and higher liquid specific heat. It is quite difficult to enhance the heat transfer rate of a PHP just by application of pure working fluids, because of the limits of the thermodynamic and physical properties. To solve this problem many researchers explored the effect of use of mixture of different fluids. The temperature-slip and 
concentration-slip achieved with the mixture contributed to special heat transfer performances of PHP that is different from pure working fluids.

Saiyan Shi et al. [72] studied the thermal characteristics of a CLPHP with ethanol as base fluid in mixtures. The authors observed that for the low FRs viz. 45\% and 55\%, the component of mixture having lower boiling point had a phase-change inhibition on the evaporation of the component having high boiling point, resulting into delayed dry-out and low thermal resistance. They also observed that for relatively high FRs viz. $62 \%, 70 \%$ and $90 \%$, the thermal performance of CLPHP with pure working fluids as compared with mixture as the working fluid. Pramod R. P. et al. [76], also studied effect of binary fluids mixture on the thermal characteristics of CLPHP. They found that the heat input at which dry-out took place for the water-methanol, water-acetone and water-ethanol CLPHPs were at $85 \mathrm{~W}, 80 \mathrm{~W}$ and $90 \mathrm{~W}$ respectively. It was concluded that dryout heat input was dependent on the algebraic mean values of the BP value of a binary mixture.

\section{NOVEL TECHNIQUES FOR HEAT TRANSFER ENHANCEMENT}

Besides the above investigations performed to study the effect of various parameter on the heat transfer performance of PHPs, there are several novel techniques like use of nanofluids, magnetic field and surfactant been investigated in order to enhance heat transfer rate by them. Gist of results of such investigations is summarized below.

\section{Use of Nanofluids and / Or Magnetic Field}

The push for 'Going Nano' have led many researchers throughout the world to explore the possibility of employing of nanofluids in PHPs. Effect of use of nano-fluids on the heat transfer performance of PHPs have been studied by several researchers. B. Verma et al. [60] investigated performance of PHP with $\mathrm{Al}_{2} \mathrm{O}_{3}$ nanofluid of different concentrations and at different orientation. It is found that there was considerable decrease in thermal resistance as compared to that of the base fluid as the concentration increases from $0.25 \%$ to $1.0 \%$ but the thermal performance deteriorated as the concentration increased by $1.25 \%$ to $2.5 \%$. Thus, there existed an optimum concentration of nanoparticles for which the PHP gave the best heat transfer performance, which was $1.0 \%$. Qingping Wu et al. [75] experimentally studied the thermal behavior of a flat plate closed loop pulsating heat pipe abbreviated as FCLPHP. They employed C60 nanofluid as working fluid for three different concentrations of $0.1,0.2$ and $0.3 \%$ by weight. They observed that that increase in nanofluid concentration lead to increase in heat transfer rate but with simultaneous increase in tendency to dry out. Hossein Afshin et al. [77] explored impact of use of ferrofluid, its concentration in water as base fluid, orientation, along with the use of magnetic field on OLPHP operation. They observed improvement in thermal performance when magnetic field is applied. Many studies on the effect of use of different nanofluids applying copper, silver colloidal, hydroxylated MWNTs, Graphene and $\mathrm{TiO}_{2}$ (titania) nano-particles and water as base fluid on the PHP performance indicated augmentation in the heat transfer limit by a significant amount $[77,78,79,90]$.

\section{Use of Surfactant}

The tubes of PHP are generally capillary type, thus variation of surface tension of the working fluid could significantly affect the flow characteristics of any type of PHP whether CLPHP or OLPHP. Thus, it becomes necessary to understand impact of surface tension on the heat transfer characteristics of PHP by varying the quantity of different surfactants to the base fluid. The surfactant when added to working fluid decreases the surface tension aiding the bubble formation which helps in early start-up of the heat pipe. Many researchers have found that use of surfactant has led to significant decrease in thermal resistance of the PHP owing to the decrease in surface tension. Surfactants like Cetyl Trimethyl Ammonium Bromide, Sulfate (SDS), Sodium Stearate, Triton X-100 and Sodium Dodecyl added to water as base fluid for the PHP led to same afore mentioned results [43, 91, 92, 93]. Hongna Zhanget al. [94] investigated the thermal characteristics of CLPHP for different concentrations of surfactant Cetyltrimethyl Ammonium Chloride (CTAC). Methanol and Ethanol were taken as base fluid and compared it with that of water. The least $R_{\text {th }}$ was attained by solution with 2000ppm CTAC for FRs 35\% and 50\%, establishing that the CTAC solution performs better than DI water in the PHP. These investigations ascertain that thermodynamic and physical properties of surfactant solution if used as a working fluid in a PHP enhances the heat transfer performance of a PHP. 


\section{APPLICATIONS}

Many investigations have been performed giving the insight of the PHP technology been tested and applied in some domestic or industrial application. This section contains review of such research papers. Applications of pulsating heat pipe ranging from electronics to heat recovery have been discussed.

\section{Electronics}

Zirong Lin et al. [95] developed a heat sink utilizing a plate type PHP for cooling of LED light. The Thermal Design Power (TDP) of LED light was 64W. It was observed that when a PHP was utilized, its temperature reduced significantly indicating it to be an effectual solution for LED cooling. Hui-Ying Wu et al. [96] proposed silicon-based micro-pulsating heat pipe capable of being directly fabricated as an integral part of a semiconductor chip which could significantly enhance the temperature uniformity and decreases the maximum localized temperature. Li Jia et al. [97] performed simulation of a cooling system for rack in a data centre implementing a PHP and inner duct for inner air cooling. The simulation showed that by implementing an internal duct along with PHP, there was improvement in temperature gradient of the air flowing through rack and number of hot spots got reduced. Omar Suleman et al. [98], investigated OLPHP using NovecTM 649 and NovecTM 774 as working fluids with the aim of recognizing the operating limits and conditions pertinent to embedded power electronics cooling. OLPHP employing NovecTM 649 as working fluid outperformed the copper (layers of which are utilized in current techniques to lessen the hot spots and spread heat) with a better thermal conductivity by 12.5 times. Qin Sun et al. [99,100], proposed micro-CLPHP of trapezoidal channels etched on a silicon wafer with eleven turns and HFE-7100 as working fluid, for MEMS application. Mike R. Wilson et al. [101], proposed embedding of a PHP into a thermal strap so as to improve its thermal conductance. They found that the thermal strap with PHP outperformed the conventional strap for heat input of $10 \mathrm{~W}$, while having a lesser mass and greater flexibility.

\section{Cryogenics}

Besides high temperature appliances, PHPs could also be applied in systems and devices with extremely low operating temperatures known as cryogenic systems. Maria Barba et al. [44], experimentally investigated three large-scale horizontal cryogenic PHPs having length of $3.7 \mathrm{~m}$. Nitrogen was used as working fluid and the operating temperature range was $75 \mathrm{~K}$ to $90 \mathrm{~K}$. 36 parallel channels PHP achieved a definite degree of stability after operation period of 30 minutes attaining effective thermal conductivity around $200 \mathrm{~kW} / \mathrm{mK}$ for $10 \mathrm{~W}$ heat input. For $5 \mathrm{~W}$ heat input an effective thermal conductivity close to $300 \mathrm{~kW} / \mathrm{mK}$ was achieved after operation period of forty minutes. Luis Diego Fonseca et al. [46], successfully operated a cryogenic PHP having forty parallel tubes and nitrogen as working fluid and at various fill ratios. Bo Jiao et al. [70], successfully operated two cryogenic PHPs with 100 and $500 \mathrm{~mm}$ adiabatic lengths with hydrogen as working fluid capable of transporting heat over a long distance. K. Natsume et al. [102], successfully implemented a prototype of a PHP suitable for cooling HTS (High Temperature superconducting) magnets operating on cryogenic working fluids like $\mathrm{Ne}, \mathrm{H}_{2}$ and $\mathrm{N}_{2}$. Luis Di. F. et al. [103] proposed a novel cooling system applying a PHP with helium as working fluid, suitable for cooling of low temperature superconducting magnets. Luis D. F. et al. [105] presented a design of PHP core operating at temperatures range of $77 \mathrm{~K}$ to $80 \mathrm{~K}$. Nitrogen was utilized as the working fluid. Xiao Sun et al. [105], studied the thermal behavior of cryogenic PHPs, with one using hydrogen and other using helium as working fluids for cryogenic application. They found that the FR of a cryogenic PHP varies significantly with the operating temperature and with increase in FR, the effective thermal conductivity initially increases and after that decreases.

\section{Solar Energy}

With the fast running down of fossil fuels, world is focusing on non-conventional sources of energy. Solar energy is a obviously most propitious of all energy sources because of its ease of availability and renewability. There have been many successful implementations of PHPs in devices operating on solar energy. Kim-Bao Nguyen et al. [106], investigated performance of a solar collector equipped with a CLPHP and achieved thermal efficiency up to $70 \%$ for a FR of $60 \%$. Jong Soo Kim et al. [107], integrated a novel U type PHP and Double U type in two solar collectors. They achieved efficiency of $61.3 \%$ and $46.8 \%$ with U type PHP and Double U type respectively for water flow rate of $2 \mathrm{~kg} / \mathrm{min}$. Both solar collectors worked with great reliability for the water flow rate kept at standard values. M. Soltanieh et al. [108], investigated effect of an extra-long PHP (ELPHP) integrated in a solar thermal collector for water heating. The thermal efficiency of the 
solar water heater with PHP mode was found to be 53.79\%, for fill ratio of 70\%. H. Kargar Sharif Abad et al. [109], proposed a new type of solar desalination system integrated with a PHP, with notable rate of production of desalinated water. The highest production rate was found to reaching $875 \mathrm{~mL} /\left(\mathrm{m}^{2} \mathrm{~h}\right)$. Yuechao D. et al. [110] proposed a flat plate solar collector having array of micro-channel heat pipes, for which the maximum instantaneous efficiency was found to be $80 \%$ which is $11.4 \%$ superior to the technical required value in Chinese national standard. Rong Ji Xu et al. [111], investigated a solar collector that integrates a CLPHP and a parabolic concentrator. For a direct normal irradiance of $800 \mathrm{~W} / \mathrm{m}^{2}$, the instant thermal efficiency of $50 \%$ was attained.

\section{Aerospace}

Mostly the experimentations on PHP are done for Earth gravity conditions. For aerospace applications it is necessary for any device to operate reliably under micro gravity condition as well as hyper gravity conditions. Few researchers have explored the possibility to use PHP under microgravity as well as hyper-gravity conditions. M. Mameli et al. [58, 83], proposed a new concept of using a PHP with a diameter larger than the capillary dimensions. Except for the ground test in horizontal orientation the device operated well in both ground and in hyper/micro gravity conditions and inclination. L. Araneo et al. [112], proposed use of CLPHP using FC72 as working fluid for space application, which was tested for ground as well as in micro and hyper gravity conditions. They tested made copper CLPHP with 32 parallel channels and it was found its horizontal operation on ground was quite similar to that in microgravity operation. They made conclusion that microgravity tests for CLCHP are not necessary for the space application assessment. F Creatini et al. [113] tested and successfully operated two CLPHPs, one with $3 \mathrm{~mm}$ and other with $1.6 \mathrm{~mm}$ diameter, on board of REXUS 18 sounding rocket with the aim to explore its performance over a rather long microgravity period (around 90s).

\section{MISCELLANEOUS}

Zilong Deng et al. [34] proposed and tested a conceptual devise making use of anti-gravity Pulsating Heat Pipe. The device was to be applied for recovery waste heat by transferring heat from the high-temperature exhaust to the low temperature fuel for preheating. The PHP showed much better thermal performance in comparion with the pure copper heat transfer medium conventionally used. Oguzhan Der et al. [57] proposed pulsating heat stripes (PHS) based on PHP for effective thermal management of passive nature in devices and materials, such as fabrics equipped with microelectronic devices, whose thermal management is severely hindered at present by mechanical, size, or weight constraints. R. Khodami et al. [114] presented a prototype of a heat exchanger having an exhaust path, an air path and a array of pulsating heat pipes effective for heat recovery from chimneys to reduce the fuel consumption. Adi Winarta et al. [115], proposed design of long CLPHP for heat recovery. They experimentally investigated it to determine the impact of heat input on heat transfer characteristics for two different fluids methanol and ethanol, for which the resistance was estimated to be $0.258^{\circ} \mathrm{C} / \mathrm{W}$ and $0.286^{\circ} \mathrm{C} / \mathrm{W}$ respectively. Govinda Mahajan et al. [116] proposed use of finned OHP Heat Recovery Ventilator for heat exchange between streams of air counter flowing in HVAC system. The system presented potential in effectively decreasing the energy consumption and thus the operating cost of air handling units (AHU) in buildings.

V. Ayel et al. [117] performed experimental studies of an OLPHP specially developed for an electronic thermal management of a hybrid vehicle. It was observed that PHP always successfully operated reliably and satisfactory reproducibility, during the start-up or normal operating condition. Zhonghao Rao et al. [118], proposed successful PHP designed especially for thermal management of battery of an electric vehicle. Zhonghao Rao et al. [119] later proposed a phase change material/pulsating heat pipe based battery cooling system which was found to be more effective in cooling than the PHP-cooled system.

\section{FUTURE SCOPE}

According to the authors knowledge no investigations have been done in recent years on the effect of the material of construction on startup and operational behavior of PHP. The thermal conductivity of the material of construction plays an important role on the rate of heat transfer to the working fluid thus could affect the bubble formation at the start of the device affecting the starting characteristics. Thus, there is need of investigation of impact of the material of construction. Use of nanofluids have proven to be prolific in PHPs, but stability of same have been least explored. Stability of the nanofluids is a vital factor which has to be considered for any application. There are numerous techniques that leads to different levels of stability of nanofluids. One of them is regulating the $\mathrm{pH}$ of nanofluids. The impact of nanofluids' $\mathrm{pH}$ on the performance of PHP is a promising 
case to be investigated [90]. PHP makes use of curved tubes. The effect of bending of fluid channel on its fluid dynamics should be explored.

\section{CONCLUDING REMARKS}

An overview of fundamentals of PHPs have been discussed at the start of this review. Recent techniques of theoretical and numerical modeling of PHPs capable of predicting its thermal performance under various operating conditions has been discussed. Although analytical and numerical analysis of PHPs have progressed notably over the recent years, for further understanding of the complex nature of the physical phenomena involved in PHPs, more fundamental studies are required to be performed. Vast experimental data available is provided concisely in tabular form. Later the conclusions deduced regarding effects of different parameters like I.D., FR, orientation, thermo physical properties of working fluid, heat input, etc. on the thermal behavior of the PHP has been reviewed. The review ends with the discussion of experiments performed on PHPs focused on particular applications and future scope.

\section{ACKNOWLEDGMENTS}

The authors are indebted to the reviewers for their invaluable feedbacks and suggestions, which have been very useful in improving the worth of the paper. The authors did not receive any funding for this work.

\section{NOMENCLATURE}

\begin{tabular}{|c|c|}
\hline A & Area, $\mathrm{m}^{2}$ \\
\hline Bo & Bond number \\
\hline $\mathrm{c} / \mathrm{s}$ & cross section \\
\hline CLPHP & Closed loop Pulsating Heat Pipe \\
\hline $\mathrm{D}$ & Tube Diameter, m \\
\hline DI & Deionised \\
\hline Eö & Eötvös Number \\
\hline FR & Filling Ratio, \% \\
\hline $\mathrm{g}$ & Gravitational Acceleration, $\mathrm{m} / \mathrm{s}^{2}$ \\
\hline $\mathrm{Ja}$ & Jakob Number \\
\hline $\mathrm{Ka}$ & Karman Number \\
\hline $\mathrm{L}$ & Length, $\mathrm{m}$ \\
\hline $\mathrm{N}$ & Number of Turns \\
\hline OLPHP & Open loop Pulsating Heat Pipe \\
\hline PHP & Pulsating Heat Pipe \\
\hline PHS & Pulsating Heat Stripe \\
\hline $\operatorname{Pr}$ & Prandtl Number \\
\hline$\dot{q}$ & Heat Flux, W/m² \\
\hline $\mathrm{Q}$ & Heat Transfer Rate, W \\
\hline $\mathrm{R}_{\mathrm{th}}$ & Thermal Resistance, K/W \\
\hline $\mathrm{K}_{\mathrm{eff}}$ & Effective Thermal Conductivity, W/mK \\
\hline $\mathrm{T}$ & Temperature, $\mathrm{K}$ \\
\hline \multicolumn{2}{|c|}{ Greek Symbols } \\
\hline$\beta$ & inclination angle with respect to the horizontal, radians \\
\hline$\rho$ & density, $\mathrm{kg} / \mathrm{m}^{3}$ \\
\hline$\sigma$ & surface tension, $\mathrm{N} / \mathrm{m}$ \\
\hline \multicolumn{2}{|c|}{ Subscripts } \\
\hline$a$ & adiabatic section \\
\hline $\operatorname{avg}$ & average \\
\hline$c$ & condenser section \\
\hline crit & critical \\
\hline$e$ & evaporator section \\
\hline eff & effective \\
\hline$l i q$ & liquid \\
\hline$t$ & total length \\
\hline vap & vapour \\
\hline
\end{tabular}

\section{REFERENCES}

[1] Himel B, Mohammad A, Md Nuruzzaman, Quamrul I, Chowdhury M. Effect of filling ratio on heat transfer characteristics and performance of a closed loop pulsating heat pipe. In: $5^{\text {th }}$ BSME International Conference on Thermal Engineering, pp. 88-95; 2013. 
[2] Pachghare PR, Ashish MM. Effect of pure and binary fluids on closed loop pulsating heat pipe thermal performance. In: Chemical, Civil and Mechanical Engineering Tracks of $3^{\text {rd }}$ Nirma University International Conference, pp. 624-629; 2013.

[3] Mohammad BS, Amir F, Yuwen Z. Thermal Modeling of Unlooped and Pulsating Heat Pipes. ASME Journal of Heat Transfer, 2001; 123(6): 1159-1172.

[4] Sameer K, Xiaoyu C, Manfred G. Thermal performance modeling of pulsating heat pipes by artificial neural network. In: $12^{\text {th }}$ International Heat Pipe Conference, Moscow, Russia, pp. 215-219; 2002.

[5] Sameer K.,Piyanun C, Manfred G, Pradit T. Closed loop pulsating heat pipes part B:visualization and semiempirical modeling. Applied Thermal Engineering, 2003; 23(16): 2021-2033.

[6] Dobson RT. Theoretical and experimental modeling of an open oscillatory heat pipe including gravity. International Journal of Thermal Sciences, 2004; 43(2): 113-119.

[7] Sankulchangsatjatai P, Terdtoon P, Wongratanaphisan T, Kamonpet P, Murakami M. Operation modeling of closed-end and closed-loop oscillating heat pipes at normal operating condition. Applied Thermal Engineering, 2004; 24(7): 995-1008.

[8] Ma HB, Hanlon MA, Chen CL. An investigation of oscillating motions in a miniature pulsating heat pipes. Microfluidics and Nanofluidics, 2006; 2(2): 171-179.

[9] Sankulchangsatjatai P, Chareonsawan P, Waowaew T, Terdtoon P, Murakami M. Mathematical modeling of closed-end pulsating heat pipes operating with a bottom heat mode. Heat Transfer Engineering, 2008; 29(3): 239-254.

[10] Narasimha KR, Sridhara SN, Rajagopal MS and Seetharamu KN. Parametric studies on pulsating heat pipe. International Journal of Numerical Methods for Heat \& Fluid Flow, 2010; 20(4): 392-415.

[11] Mauro M, Marco M, Stefano Z. Numerical investigation of the effects of orientation and gravity in a closed loop pulsating heat pipe. Microgravity Sci. Technology, 2012; 24(2): 79-92.

[12]Peng $\mathrm{CH}$ and Hongbin Ma. A mathematical model of an oscillating heat pipe. Heat Transfer Engineering,2011; 32(11-12): 1037-1046.

[13] Mameli M, Marengo M, Zinna S. Numerical model of a multi-turn closed loop pulsating heat pipe: Effects of the local pressure losses due to meanderings. International Journal of Heat and Mass Transfer, 2012; 55(4) :1036-1047.

[14] Sejung K, Yuwen Z, Jongwook C. Effects of fluctuations of heating and cooling section temperatures on performance of a pulsating heat pipe. Applied Thermal Engineering, 2013; 58(1-2): 42-51.

[15] Yin D, Rajab H, Ma HB. Theoretical analysis of maximum filling ratio in an oscillating heat pipe. International Journal of Heat and Mass Transfer, 2014: 353-357.

[16] Gursel G, Frijns AJH, Homburg FGA, Van Steenhoven AA. A mass-spring-damper model of a pulsating heat pipe with a non-uniform and asymmetric filling. Applied Thermal Engineering, 2015; 91(5): 80-90.

[17] Patel VM, Mehta HB. Thermal performance prediction models for a pulsating heat pipe using artificial neural network (ann) and regression/correlation analysis (rca). Sadhana, 2018, 43: 184.

[18] Xiangdong L, Yingli H. Numerical Simulation of Vapor-Liquid Two-Phase Flow In A Closed Oscillating Heat Pipe. In: International Mechanical Engineering Congress \& Exposition, Florida, USA pp.609-617; 2009.

[19] Subhash N, Pramod P. Experimental and CFD Analysis of closed loop Pulsating Heat Pipe with DI-water. In: International Conference on Energy Efficient Technologies for Sustainability, pp.185-190; 2013.

[20] Zirong L, Shuangfeng W, Ryo S, Zhang LW. Simulation of a miniature oscillating heat pipe in bottom heating mode using CFD with unsteady modeling. International Journal of Heat and Mass transfer, 2013; 57(2): 642-656.

[21] Rudresha S, Vijee K. CFD Analysis and Experimental Investigations on Thermal Performance of Closed loop Pulsating Heat pipe using different Nanofluids. International Journal of Advanced Research, 2014; 2(8): 753-760.

[22] Pramod P, Ashish M. Thermo-hydrodynamics of closed loop pulsating heat pipe: an experimental study. Journal of Mechanical Science and Technology,2014;28 (8) ; 3387-3394.

[23] Jiansheng W, He M, Qiang Z. Effects of the evaporator and condenser length on the performance of pulsating heat pipes. Applied Thermal Engineering, 2015; 91(5): 1018-1025.

[24] Mohd AH, Md Azizuddin, Md Khalid R. Cfd and volume fraction analysis of closed loop pulsating heat pipe (clphp). IOSR Journal of Mechanical and Civil Engineering, 2016; 13(5): 88-94.

[25] Jiaqiang E, Xiaohuan Z, Yuanwang D, Hao Z. Pressure distribution and flow characteristics of closed oscillating heat pipe during the starting process at different vacuum degrees. Applied Thermal Engineering, 2016; 93: 166-173.

[26] Venkatasuresh J, Bhramara P. Cfd analysis of copper closed loop pulsating heat pipe. In: Materials Today, pp. 5487-5495; 2018.

[27] Ashutosh G, Ajit P. Cfd modeling for thermal performance of Closed Loop Pulsating heat pipe in bottom heated mode. In: Sixth International Conference on Advances in Civil, Structural and Mechanical Engineering, pp. 46-50; 2017. 
[28] Sameer K, Manfred G, Charoensawan P, Rittidech S, Terdtoon P. Closed and open loop pulsating heat pipes. In: 13th International Heat Pipe Conference, Shanghai, China, 2004.

[29] Meena P, Rittidech S, Tammasaeng P. Effect of inner diameter and inclination angles on operation limit of closed-loop oscillating heat-pipes with check valves. American Journal of Engineering and Applied Sciences, 2008; 1(2): 100-103.

[30] Kammuang-Lue N, Sakulchangsatjatai P, Terdtoon P. Effect of working fluids and internal diameters on thermal performance of vertical and horizontal closed-loop pulsating heat pipes with multiple heat sources. Thermal Science, 2016; 20(1): 77-87.

[31] Islam F, Akhter F, Haider SB, Ali M. Effect Of Inner Diameter On The Thermal Performance Of Closed Loop Pulsating Heat Pipe. International Journal of Mechanical and Production Engineering, 2017; 5(7): 69-72.

[32] Kwon G. H. and Kim S.J., Analysis of Pulsating Heat Pipe with a Dual-Diameter Tube,10th International Conference on Heat Transfer.Fluid Mechanics and Thermodynamics, 14-26 July, 2014.

[33] Keerthi K, Srinath M, Ranjit KG. Effect of working fluid, heat input and filling ratio's on performance of closed loop pulsating heat pipe. International Journal of Advances in Scientific Research and Engineering, 2017; 3(1): 209-215.

[34] Zilong D, Yi Z, Xiangdong L, Bingping Z, Yongping C. Experimental study on thermal performance on anti-gravity pulsating heat pipe and its application on heat recovery utilization. Applied Thermal Engineering, 2017; $125: 1368-1378$.

[35] Takawale, Abraham S, Pattamatta A, Sielaff A, Stephan P. A comparative study of flow regimes and thermal performance between flat plate pulsating heat pipe (fpphp) and capillary tube pulsating heat pipe(ctphp). In: 10th International Conference on Boiling and Condensation Heat Transfer, Nagasaki, Japan; 2008.

[36] Barua H, Ali M, Md. Nuruzzaman, Islam MQ, Chowdhury MF. Effect of filling ratio on heat transfer characteristics and performance of a closed loop pulsating heat pipe. In: 5th BSME International Conference on Thermal Engineering, Procedia Engineering, pp. 88 - 95; 2013.

[37] Sarangi RK, Rane MV. Experimental investigations for start up and maximum heat load of closed loop pulsating heat pipe. In: 3rd Nirma University International Conference on Engineering, pp. 683 - 687, 2012.

[38] Hua H, Xiaoyu C, Yue Z, Shende S. A comparative study of the behaviour of working fluids and their properties on the performance of pulsating heat pipes (PHP). International Journal of Thermal Sciences, 2014; 82: $138-147$.

[39] Xiaoyu C, Yue Z, Zhihua L, Shende S. Combination study of operation characteristics and heat transfer mechanism for pulsating heat pipe. Applied Thermal Engineering,2014; 65(1-2): 394 - 402.

[40] Nandan S, Das PK, Sharma PK. Influence of process variables on the hydrodynamics and performance of a single loop pulsating heat pipe. International Journal of Heat and Mass Transfer, 2014; 74: 238-250.

[41] Mameli M, Manno V, Filippeschi S, Marengo M. Thermal instability of a Closed Loop Pulsating Heat Pipe: Combined effect of orientation and filling ratio. Experimental Thermal and Fluid Science, 2014; 59: 222229.

[42] Dong X, Laifeng L Huiming L. Experimental investigation on the thermal performance of helium based cryogenic pulsating heat pipe. Experimental Thermal and Fluid Science, 2016; 70: 61-68.

[43] Meibo X, Ruixiang W, Rongji X. Experimental study on thermal performance of a pulsating heat pipe with surfactant aqueous solution. International Journal of Heat and Mass Transfer, 2018; 127: 903-909.

[44] Maria B, Romain B, Antoine B, Bertrand B. Experimental study of large-scale cryogenic pulsating heat pipe. In: Cryogenic Engineering Conference, USA, pp.1-8; 2017.

[45] Kammuang-lue N, On-ai K, Sakulchangsatjatai P, Terdtoon P. Thermal characteristics of a rotating closedloop pulsating heat pipe affected by centrifugal accelerations and numbers of turns. Journal of Mechanical Engineering, 2017; 4(3): 35-50.

[46] Luis Diego F, Franklin M, John P. Experimental heat transfer analysis of a cryogenic nitrogen pulsating heat Pipe at various liquid fill ratios. Applied Thermal Engineering, 2018; 130: 343-353.

[47] De Vries SF, Florea D, Homburg FGA, Frijns AJH. Design and operation of a Tesla-type valve for pulsating heat pipes. International Journal of Heat and Mass Transfer, 2017; 105: 1-11.

[48] Chen F, Zhenping W, Haijun M, Heng T, Longsheng L, Yong T. Heat transfer characteristics of a novel closed-loop pulsating heat pipe with a check valve. Applied Thermal Engineering, 2018; 141: 558-564.

[49] Pastukhov VG, Maydanik YF, Development of pulsating heat pipe with directional circulation of a working fluid. Applied Thermal Engineering, 2016; 109: 155-161.

[50] Wookyoung K, Hyung YN, Sunjoo L, Sung Jin K. Experimental Investigation on the Thermal Performance of Double-Condenser Pulsating Heat Pipes. In: 10th International Conference on Boiling and Condensation Heat Transfer Nagasaki, Japan, 2018.

[51] Byeongchan K, Longnan L, Jihoon K, Daejoong K. A study on thermal performance of parallel connected pulsating heat pipe. Applied Thermal Engineering, 2017; $126: 1063-1068$. 
[52] Lutfor MR, Fariha M, Sumaiya N, Sultana RA, Mohammad A. Effect of fin and insert on the performance characteristics of open loop pulsating heat pipe (olphp). 6th BSME International Conference on Thermal Engineering (ICTE 2014), Procedia Engineering, 2015; 105: 105-112.

[53] Chih-Yung T, Kai-Shing Y, Kuo-Hsiang C, Ming-Shan J, Chi-Chuan W. Investigation of the performance of pulsating heat pipe subject to uniform/alternating tube diameters. Experimental Thermal and Fluid Science, 2014; 54: 85-92.

[54] Chih-Yung T, Kai-Shing Y, Kuo-Hsiang C, Ming-Shan J, Chi-Chuan W. Investigation of the evacuation pressure on the performance of pulsating heat pipe. International Communications in Heat and Mass Transfer, 2017; 85: 23-28.

[55] Luis Betancur, Daniele Mangini, Arthur Facin, Marcia Mantelli, Kleber Paiva, Bruna Coutinho, Marco Marengo. Experimental study of start-up in a closed loop pulsating heat pipe with alternating superhydrophobic channels. In: Joint 19th IHPC and 13th IHPS, Italy, 2018.

[56] Oguzhan D, Marco M, Volfango B. A low cost flexible pulsating heat pipe technology. In: 3rd Thermal and Fluids Engineering Conference (TFEC), FL, USA, pp. 4-7; 2018.

[57] Oguzhan D, Marco M, Volfango B. Thermal performance of pulsating heat stripes (PHS) built with plastic materials. In: Joint 19th IHPC and 13th IHPS, Pisa, Italy, 2018.

[58] Mangini D, Mameli M, Georgoulas A, Araneo L, Filippeschi S, Marengo M. A pulsating heat pipe for space applications: ground and microgravity experiments. International Journal of Thermal Sciences, 2015; 95 : 53-6.

[59] Sedighi E, Amarloo A, Shafii MB. Experimental investigation of the thermal characteristics of single-turn pulsating heat pipes with an extra branch. International Journal of Thermal Sciences, 2018; 134: 258-268.

[60] Verma B, Yadav VL, Srivastava KK. Experimental study on thermal performance of pulsating heat pipe with Al2O3-deionized water nanofluid at different orientations. Journal of Enhanced Heat Transfer, 2013; 20 (2): 153-163.

[61] Lutfor MR, Fariha M, Asfia TT, Sumaiya N, Mohammad A. Experimental Investigation on heat transfer characteristics of an open loop pulsating heat pipe (OLPHP) with fin. In: 6th BSME International Conference on Thermal Engineering, Dhaka, pp. 113 - 120; 2015.

[62] Lutfor MR, Rasel S, Islam T, Noor H, Mohammad A. An experimental investigation on the effect of fin in the performance of closed loop pulsating heat pipe (CLPHP). In: 6th BSME International Conference on Thermal Engineering, Procedia Engineering, Dhaka, pp. 137-144; 2015.

[63] Suchana AJ, Mohammad A, Md. Quamrul I. Effect of inclination angles on heat transfer characteristics of a closed loop pulsating heat pipe (CLPHP). In: 5th BSME International Conference on Thermal Engineering, Dhaka, pp.82- 87; 2015.

[64] Xue Z, Qu W. Experimental study on effect of inclination angles to ammonia pulsating heat pipe. Chinese Journal of Aeronautics, 2014; 27(5): 1122-1127.

[65] Maziar M, Mehdi T, Shahab H. Open-loop pulsating heat pipes charged with magnetic nanofluids: powerful candidates for future electronic coolers. Nanoscale and Microscale Thermophysical Engineering, 2014 ;18: 18-38.

[66] Soohwan J, Sung JK. Comparison of the thermal performances and flow characteristics between closedloop and closed-end micro pulsating heat pipes. International Journal of Heat and Mass Transfer, 2016; 95: 890901.

[67] Lim J, Jin Kim S. Fabrication and experimental evaluation of a polymer-based flexible pulsating heat pipe. Energy Conversion and Management, 2018; 156: 358-364.

[68] Vincent A, Yves B, Cyril R, Gwenael B. Experimental study of pulsating heat pipes tested in horizontal and vertical positions. In: 15th International Heat Pipe Conference (15th IHPC), Clemson, USA, pp. 25-30, 2010.

[69] Masaru S, Shun O, Hiroyuki O. Experimental investigation of design factors on heat transfer performance of meter-scale oscillating heat pipe. In: 48th International Conference on Environmental Systems, New Mexico, pp.1-7; 2018.

[70] Zhihua G, Xiao S, Bo J, Dongyang H, Haoren D, Shunhao W, John M. Pfotenhauer. Experimental study on a hydrogen closed loop pulsating heat pipe with different adiabatic lengths. Heat Transfer Engineering, 2018; 40(3-4):205-214.

[71] Shung-Wen K, Yao-Chun W, Ying-Chang L, Hsin-Min L. Visualization and thermal resistance measurements for a magnetic nanofluid pulsating heat pipe. Applied Thermal Engineering, 2017; 126: 10441050 .

[72] Saiyan S, Xiaoyu C, Hua H, Jianhua W, Zhihua L. A study of the heat transfer performance of a pulsating heat pipe with ethanol-based mixtures. Applied Thermal Engineering, 2016; 102: 1219-1227.

[73] Shekhar K, Manoj R, Dankal K, Deepu K, Raghavjee T. Experimental Analysis of Closed Loop Pulsating Heat Pipe By Using Different Working fluids. International Journal of Research; 7(6): 84-91. 
[74] Lutfor MR, Sumaiya N, Rasel S, Fariha M, Mohammad A. Effect of fin and insert on the performance characteristics of close loop pulsating heat pipe (CLPHP). In: 6th BSME International Conference on Thermal Engineering, pp. 129-136, 2015.

[75] Qingping W, Rongji X, Ruixiang W, Yanzhong L. Effect of C60 nanofluid on the thermal performance of a flat-plate pulsating heat pipe. International Journal of Heat and Mass Transfer, 2016; 100: 892-898.

[76] Pramod P, Ashish M. Effect of pure and binary fluids on closed loop pulsating heat pipe thermal performance. In: Chemical, Civil and Mechanical Engineering Tracks of 3rd Nirma University International Conference, pp. 624-629, 2013.

[77] Maziar M , Mehdi T, Mohammad HS , Mohammad BS , Hossein A, Siamak KH. Ferrofluidic open loop pulsating heat pipes: efficient candidates for thermal management of electronics. Experimental Heat Transfer: A Journal of Thermal Energy Generation, Transport, Storage, and Conversion, 2014; 27: 296-312.

[78] Karthikeyan VK, Ramachandran K, Pillai BC, Brusly SA. Effect of nanofluids on thermal performance of closed loop pulsating heat pipe. Experimental. Thermal and Fluid Science, 2014; 54: 171-178.

[79] Meibo X, Jianlin Y, Ruixiang W. Performance of a vertical closed pulsating heat pipe with hydroxylated MWNTs nanofluid. International Journal of Heat and Mass Transfer, 2017; 112: 81-88.

[80] Mohammad AN, Roghayeh G, Mohammad HA, Gholamreza H, Mohammad BS. Experimental investigation of graphene oxide nanofluid on heat transfer enhancement of pulsating heat pipe. International Communications in Heat and Mass Transfer, 2018; 91: 90-94.

[81] Pradeep GV, Narasimha KR. Thermal performance of a vertical closed loop pulsating heat pipe and analysis using dimensionless numbers. Journal of Mechanical Engineering and Sciences, 2017; 11(4): 32403255.

[82] Yue Z, Xiaoyu C, Hua H, Shende S. The study on the difference of the start-up and heat-transfer performance of the pulsating heat pipe with water-acetone mixtures. International Journal of Heat and Mass Transfer, 2014; 77: 834-842.

[83] Mangini D, Mameli M, Fioriti D, Filippeschi S, Araneo L, Marengo M. Hybrid Pulsating Heat Pipe for space applications with non-uniform heating patterns: Ground and microgravity experiments. Applied Thermal Engineering, 2017; 126: 1029-1043.

[84] Mauro M., Marco M. and Sameer K. Local heat transfer measurement and thermo-fluid characterization of a pulsating heat pipe. International Journal of Thermal Sciences, 2014; 75: 140-152.

[85] $\mathrm{Hu} \mathrm{X}, \mathrm{Qu}$ W. Experimental and theoretical research on a ammonia pulsating heat pipe: new full visualization of flow pattern and operating mechanism study. International Journal of Heat and Mass Transfer, 2017; 106: 149-166.

[86] Harshal G, Vinayak M, Bade M, Mehta HB. Experimental investigations on pulsating heat pipe. In: The 7th International Conference on Applied Energy - ICAE 2015, Energy Procedia, pp. 3186-3191; 2015.

[87] Jianhong L, Fumin S, Dengying L. Experimental study on enhanced heat transfer characteristis of synergistic coupling between the pulsating heat pipes. In: International Conference on Future Energy, Environment and Materials, pp.1510-1516; 2012.

[88] Harshal G, Vinayak M, Bade M, Mehta HB. Experimental investigations on pulsating heat pipe. The 7th International Conference on Applied Energy - ICAE 2015, pp. 3186-3191; 2015.

[89] Ayel V, Araneo L, Scalambra A, Mameli M, Romestant C, Piteau A, Marengo M, Filippeschi S, Bertin Y. Experimental study of a closed loop flat plate pulsating heat pipe under a varying gravity force. International Journal of Thermal Sciences, 2015; $96: 23-34$.

[90] Ali A, Mohammad HS. Experimental investigation of nanofluid stability on thermal performance and flow regimes in pulsating heat pipe. Journal of Thermal Analysis and Calorimetry, 2018; 135(3):1835-1847.

[91] Manoj K, Ravi K, Arup KD, Prasanta D. Effect of surface tension of the working fluid on the performance of a closed loop pulsating heat pipe. In: 23rd National Heat and Mass Transfer Conference and 1st International ISHMT-ASTFE Heat and Mass Transfer Conference, Thiruvananthapuram, India, pp.1-8; 2015.

[92] Wang XH, Zheng HC, Si MQ, Han XH, Chen GM. Experimental investigation of the influence of surfactant on the heat transfer performance of pulsating heat pipe. International Journal of Heat and Mass Transfer, 2015; 83: 586-590.

[93] Mohammad AN, Roghayeh G, Mohammad BS, Mohammad HA. Experimental investigation of triton x100 solution on pulsating heat pipe thermal Performance. Journal of Thermophysics and Heat Transfer, 2018; 32(3):806-812.

[94] Durga B, Hongna Z, Weihua C, Fengchen L. An experimental investigation of thermal performance of pulsating heat pipe with alcohols and surfactant solutions. International Journal of Heat and Mass Transfer, 2018; $117: 1032-1040$.

[95] Zirong L, Shuangfeng W, Jiepeng H, Yanxin H, Jinjian C, Winston Z, Eton L. Heat transfer characteristics and led heat sink application of aluminium plate oscillating heat pipes. Applied Thermal Engineering, 2011; 31(14-15): 2221-2229. 
[96] Jian Q, Hui-Ying W, Qian W. Experimental investigation of silicon based micro-pulsating heat pipe for cooling electronics. Nanoscale and Microscale Thermophysical Engineering, 2012; 16(1): 37-49.

[97] Chao D, Li J, Qianyi L. Investigation on thermal design of a rack with the pulsating heat pipe for cooling CPUs. Applied Thermal Engineering, 2017; 110: 390-398.

[98] Daniel JK, Omar S, Justin G, Georgios M. Thermal performance of a pcb embedded pulsating heat pipe for power electronics applications. Applied Thermal Engineering, 2015; 98:798-809.

[99] Qin S, Jian Q, Jianping Y, Qian W. Operational characteristics of an MEMS-based micro oscillating heat pipe. Applied Thermal Engineering, 2017; 124: 1269-1278.

[100] Qin S, Jian Q, Jianping Y, Hai W. Start-up characteristics of MEMS-based micro oscillating heat pipe with and without bubble nucleation. International Journal of Heat and Mass Transfer, 2018; 122: 515-528.

[101] Mike RW, Derek WH, Steven CL. Thermal performance characterization of ted-enhanced thermal straps and thermal links with oscillating heat pipes. In: 48th International Conference on Environmental Systems, Albuquerque, New Mexico, pp.1-10; 2018.

[102] Natnume K, Minto T, Yanagi N, Tamura H. Development of a flat plate cryogenic pulsating heat pipe for improving HTS magnet cooling. Physics Procedia, 2013; 45: 233 - 236.

[103] Luis DF, Franklin M, John P. Helium based pulsating heat pipe for superconducting magnets. In: Advances in Cryogenic Engineering, pp.28-35; 2014.

[104] Luis DF, Franklin M, John P. Design and Operation of a Cryogenic Nitrogen Pulsating Heat Pipe. In: Materials Science and Engineering, pp. 1-9; 2015.

[105] Xiao S, John P, Bo J, Luis DF, Dongyang H, Zhihua G. Investigation on the temperature dependence of filling ratio in cryogenic pulsating heat pipes. International Journal of Heat and Mass Transfer, 2018; 126: 237244.

[106] Kim-Bao N, Seok-Hun Y, Jae Hyuk C. Effect of working-fluid filling ratio and cooling-water flow rate on the performance of solar collector with closed-loop oscillating heat pipe. Journal of Mechanical Science and Technology, 2012; 26(1): 251-258.

[107] Jong SK, Soo JH, Sang L. and Bang HJ. The study of evacuated solar collector using pulsating heat pipe. Frontiers in Heat Pipes (FHP), 2012; 3: 1-5.

[108] Arab M, Soltanieb M and Shafii MB. Experimental investigation of extra-long pulsating heat pipe application in solar water heaters. Experimental Thermal and Fluid Science, 2012; 42 : 6-15.

[109] Sharif Abad HK, Ghiasi M, Mamouri SJ and Shafii MB. A novel integrated solar desalination system with a pulsating heat pipe. Desalination, 2013; 3: 206-210.

[110] Yuechao D, Yaohua Z, Wei W, Zhenhua Q, Lincheng W, Dan Y. Experimental investigation of performance for the novel flat plate solar collector with micro-channel heat pipe array (MHPA-FPC). Applied Thermal Engineering, 2013; 54 (2): 440-449.

[111] RongJi X, Xiao HZ, Rui XW, ShuHui X, Hua SW. Experimental investigation of a solar collector integrated with a pulsating heat pipe and a compound parabolic concentrator. Energy Conversion and Management, 2017; 148: 68-77.

[112] Mameli M, Araneo L, Filippeschi S, Marelli L, Testa R, Marengo M. Thermal response of a closed loop pulsating heat pipe under a varying gravity force. International Journal of Thermal Sciences, 2014; 80: 11-22.

[113] Creatini F, Guidi GM, Belfi F, Cicero G, Fioriti D, Prizio DD, Piacquadio S, Becatti G, Orlandini G, A Frigerio, S Fontanesi, P Nannipieri, M Rognini, N Morganti, Filippeschi S, Marco PD, Fanucci L, Baronti F, Mameli M, Manzoni M, Marengo M. Pulsating heat pipe only for space (phos): results of the Rexus 18 sounding rocket campaign. In: 33rd UIT (Italian Union of Thermo-fluid-dynamics) Heat Transfer Conference, pp.1-11; 2015.

[114] Khodami R, Nejad AA, Khabbaz MRA. Experimental investigation of energy and exergy efficiency of a pulsating heat pipe for chimney heat recovery. Sustainable Energy Technologies and Assessments; 2016: 1117.

[115] Adi W, Nandy P, Fadli B. Thermal Performance of Oscillating Heat Pipe with Ethanol/Methanol for Heat Recovery Application Design. International Journal on Advanced Science, Engineering and Information Technology, 2017; 7(4): 1268-1274.

[116] Mahajana G, Thompson SM, Cho H. Energy and cost savings potential of oscillating heat pipes for waste heat recovery ventilation. Energy Reports, 2017; 3: 46-53.

[117] Burban G, Ayel V, Alexandre A, Lagonotte P, Bertin Y, Romestant C. Experimental investigation of a pulsating heat pipe for hybrid vehicle applications. Applied Thermal Engineering, 2013; 50(1): 94-103.

[118] Zhonghao R, Yutao H, Xinjian L. Experimental study of an OHP-cooled thermal management system for electric vehicle power battery. Experimental Thermal and Fluid Science, 2014; 57: 20-26.

[119] Qingchao W, Zhonghao R, Yutao H, Shuangfeng W. Thermal performance of phase change material/oscillating heat pipe-based battery thermal management system. International Journal of Thermal Sciences, 2016; 102: 9-16. 